\title{
Biofilm reactors for industrial bioconversion processes: employing potential of enhanced reaction rates Nasib Qureshi*1, Bassam A Annous ${ }^{2}$, Thaddeus C Ezeji ${ }^{3}$, Patrick Karcher ${ }^{3}$ and Ian S Maddox ${ }^{4}$
}

Address: ${ }^{1}$ National Center for Agricultural Utilization Research, United States Department of Agriculture**, Agricultural Research Service, Fermentation Biotechnology Unit, 1815 N University Street, Peoria, IL 61604, USA, 2Eastern Regional Research Center, United States Department of Agriculture, Agricultural Research Service, 600E Mermaid Lane, Wyndmoor, PA 19038, USA, 3University of Illinois, Biotechnology \& Bioengineering Group, Department of Food Science \& Human Nutrition, 1207 W Gregory Drive, Urbana, IL 61801, USA and ${ }^{4}$ Massey Univesity, Institute of Engineering \& Technology, Palmerston North, New Zealand

Email: Nasib Qureshi* - QURESHIN@ncaur.usda.gov; Bassam A Annous - bannous@errc.ars.usda.gov; Thaddeus C Ezeji - ezeji@uiuc.edu; Patrick Karcher - pkarcher@uiuc.edu; Ian S Maddox - I.S.Maddox@massey.ac.nz

* Corresponding author

Published: 25 August 2005

Microbial Cell Factories 2005, 4:24 doi:10.1 186//475-2859-4-24
Received: 29 June 2005

Accepted: 25 August 2005

This article is available from: http://www.microbialcellfactories.com/content/4/I/24

(C) 2005 Qureshi et al; licensee BioMed Central Ltd.

This is an Open Access article distributed under the terms of the Creative Commons Attribution License (http://creativecommons.org/licenses/by/2.0), which permits unrestricted use, distribution, and reproduction in any medium, provided the original work is properly cited.

\begin{abstract}
This article describes the use of biofilm reactors for the production of various chemicals by fermentation and wastewater treatment. Biofilm formation is a natural process where microbial cells attach to the support (adsorbent) or form flocs/aggregates (also called granules) without use of chemicals and form thick layers of cells known as "biofilms." As a result of biofilm formation, cell densities in the reactor increase and cell concentrations as high as $74 \mathrm{gL}^{-1}$ can be achieved. The reactor configurations can be as simple as a batch reactor, continuous stirred tank reactor (CSTR), packed bed reactor (PBR), fluidized bed reactor (FBR), airlift reactor (ALR), upflow anaerobic sludge blanket (UASB) reactor, or any other suitable configuration. In UASB granular biofilm particles are used. This article demonstrates that reactor productivities in these reactors have been superior to any other reactor types. This article describes production of ethanol, butanol, lactic acid, acetic acid/vinegar, succinic acid, and fumaric acid in addition to wastewater treatment in the biofilm reactors. As the title suggests, biofilm reactors have high potential to be employed in biotechnology/bioconversion industry for viable economic reasons. In this article, various reactor types have been compared for the above bioconversion processes.
\end{abstract}

\section{Introduction}

Biochemical reactors play an important role in the biochemical industry as the rate of reaction, ease, and length of reactor operation affect reactor productivities and hence process economics $[1,2]$. In order to employ a most appropriate reactor for an industrial operation, reaction rate should be high and the reactor configuration should be simple. Under optimized parameters such as $\mathrm{pH}$, temperature, substrate, and medium components, reaction rate can be increased by increasing cell mass concentration in the reactor. There are two methods commonly used for increasing cell mass concentration inside the reactor; first, use of a permeable membrane to retain cells; and the other, use of immobilized cell technique. Membrane reactors allow passing of liquid, substrate, and product out of the reactor while retaining the cells. In these reactors, high cell concentrations can be achieved [3]. Unfortunately, for some processes such as waste water 
Table I: A comparison of different types of reactors with biofilm reactors

\begin{tabular}{|c|c|}
\hline Reactor Type & Comments \\
\hline \multicolumn{2}{|l|}{ Membrane reactor } \\
\hline Advantages & $\begin{array}{l}\text { High productivities, high cell concentration can be achieved inside the reactor, clear permeates for further } \\
\text { separation }\end{array}$ \\
\hline Disadvantages & Fouling with cells, cost prohibits their use in low cost large volume chemical production \\
\hline \multicolumn{2}{|c|}{ Immobilized cell reactors } \\
\hline \multicolumn{2}{|c|}{ Covalent bond formation } \\
\hline Advantages & High cell concentration may be achieved, high productivity \\
\hline Disadvantages & $\begin{array}{l}\text { Cell growth inside matrix may be restricted, cells leach out of the matrix and hence centrifugation of } \\
\text { effluent may be required, chemical may affect the cells }\end{array}$ \\
\hline \multicolumn{2}{|l|}{ Entrapment } \\
\hline Advantages & High cell concentration may be achieved, high productivity \\
\hline Disadvantages & $\begin{array}{l}\text { Matrix often starts disintegration with time, cells leach out of matrix, centrifugation of reactor effluents is } \\
\text { required for further separation }\end{array}$ \\
\hline \multicolumn{2}{|l|}{ Biofilm } \\
\hline Advantages & $\begin{array}{l}\text { Comparatively high reactor productivities and high cell concentrations are achieved, reactors run longer } \\
\text { and are economic to operate }\end{array}$ \\
\hline Disadvantages & Effluent centrifugation is required \\
\hline
\end{tabular}

treatment, these reactors are not preferred due to their high cost and problems with fouling. Other processes where the relatively high cost of these reactors does not allow their use include production of large volume, low cost chemicals such as vinegar or acetic acid.

Other types of reactors that offer high reaction rates are immobilized cell reactors [4]. In these reactors, high cell concentrations are achieved by fixing them on various supports. Cells can be immobilized by three different techniques; namely, adsorption, entrapment, and covalent bond formation. Entrapment and covalent bond formation require use of chemicals that add to the cost of production and perhaps restrict further propagation or increase in cell concentration inside the reactor. The third technique is of natural origin as cells "adsorb/and adhere" to the support naturally and firmly [4-6]. This technique is called "adsorption" and has been used extensively in the literature to adsorb microbial cells. Table 1 shows a comparison of these techniques with the membrane reactors. It should be noted that some microbial cells leach out from immobilized cell reactors which require separation (leached out cells in reactor effluent) prior to product removal possibly by centrifugation.

In addition to being a natural process, adsorption can be performed in place, and economical adsorbents are available. Additionally, these reactors are simple in concept and construction and the immobilization process is economical. Adsorbed cells form cell layers on the support and cell mass grows inside the reactor over time [7]. These layers of cells are called "biofilms." Biofilms can be used in various types of reactors such as continuous stirred tank reactors (CSTRs), packed bed reactors (PBRs), fluidized bed reactors (FBRs), airlift reactors (ALRs), upflow anaerobic sludge blanket (UASB) reactors, and expanded granular sludge bed (EGSB) reactors etc. [4,7-11]. In these reactors, reaction rates are usually high as compared to the other types of reactors. On the laboratory, pilot plant, and industrial scale (some), these reactors have been very successful and examples include waste water treatment [12] and vinegar or acetic acid [13] production. In addition to these, other processes that have employed these biofilm reactors include ethanol, butanol, lactic acid, fumaric acid, and succinic acid production. Since they offer high reaction rates and are economical, this review becomes their subject matter. In the authors' view, this natural process of biofilm formation can be employed to economize production of various chemicals by fermentation on a large scale [13]. In biofilm reactors, cell concentrations as high as $74 \mathrm{gL}^{-1}$ can be achieved [7]. In addition, the cell layers in bioparticles become highly active, thus contributing to the high reactor productivities. Within fluidized bed reactors, the biofilm particles are of various shapes (including spherical and irregular shapes) and these reactors can be operated for long periods of time. The amount of adsorbent that is used in these reactors is low, which also reduces the cost of the cell support. In biofilm reactors, reactor configurations can vary from a simple packed bed reactor to fluidized bed, UASB, and airlift reactors as described in this article.

\section{Biofilm Formation Various types of biofilms}

In nature, biofilms exist primarily as complex multi-species communities of bacteria in which each species fills an ecological niche within the biofilm depending on its metabolism and morphology [14]. The nature of mixed 
culture biofilms is dependent on which species are present and what role each species fills. For instance, a single species may utilize anaerobic fermentation deep within one biofilm in one environment, but may utilize an aerobic metabolism in another environment in the presence of different neighboring biofilm species. Multi-species biofilms are important clinically as well as industrially. Clinically, biofilms are important as the source of persistent infections. They are responsible for dental caries and nosocomial infections, as well as a variety of other infections and diseases [15]. Industrially, biofilms are detrimental in many cases and beneficial in many others. For instance, natural biofilms can reduce heat transfer in heat exchangers and cooling towers [16], foul reverse osmosis membranes [17], and contaminate food processing equipment [18]. Multi-species biofilms are used industrially to achieve several aims including the treatment of wastewater for removal of organics $[19,20]$ and heavy metals [21]. The presence of multiple species allows for the treatment of waste streams that are diverse in composition and that fluctuate in component concentration.

Single species biofilm are used to produce industrially important chemicals $[22,23]$. Such biofilms can exist in some situations and are important industrially, although in nature they are not the norm. For example, in nature, an immature biofilm that is resultant from the attachment and growth of a single cell may exist as a single species biofilm before incorporating other species. For chemical production, single species biofilms are important because they allow for control and maximization of desired products. In this case, a single species is inoculated into a sterile environment and allowed to form a biofilm before being used to produce a particular chemical product.

In industrial applications including wastewater treatment, usually two types of biofilms are employed, namely, biofilms that grow onto supports such as charcoal, resin, bonechar, concrete, clay brick, or sand particles, and biofilms that are formed as a result of flocs and aggregate formation. On the above supports, biomass grows all around the particles and the size of the biofilm particles grows with time usually to several $\mathrm{mm}$ in diameter. The density of the support particles is usually higher than the fermentation broth and for this reason bioparticles tend to remain in the lower section of the reactor. Another type of biofilm is where no support is used and cells form biomass granules and flocs that also grow in size with time. This type of biofilm is called granular biofilm and the reactor where this biofilm is used is called granular biofilm reactor. Granule formation may take from several weeks to several months. The cells produce extracellular polymeric substances (EPS) that binds the cells firmly in the form of flocs and aggregates. The most commonly used bioreactors that fall in this category are upflow anaer- obic sludge blanket (UASB) reactors that are used to treat domestic and industrial wastewater anaerobically. Sponza [24] examined anaerobic granulation process in a UASB to remove tetrachloroethylene. In some cases expanded bed biofilm reactors have been used with granular biofilm particles that are called expanded granular sludge bed (EGSB) reactors.

\section{Mechanism of biofilm formation}

A biofilm is defined as a structured community of bacterial cells enclosed in a self-produced polymeric matrix and adherent to an inert or living surface [15]. In general, there are four stages to the development of a mature biofilm: initial attachment, irreversible attachment by the production of extracellular polymeric substances (EPS), early development, and maturation of biofilm architecture [14].

The life of a biofilm starts with the planktonic or free floating cell. In order for a planktonic cell to attach to a surface, it must first interact with the surface. Surfaces immersed in an aqueous solution usually acquire a surface charge which attracts and concentrates inorganic solutes, and charged or highly polar organic molecules. The concentration of cations, glycoproteins, proteins, and organic molecules at the surface can provide a relatively nutritious zone for bacteria compared to the bulk aqueous environment [25]. In addition, fluid flow in the boundary region near the surface can be considered negligible which allows bacteria to approach the surface. Once near the surface, it will either approach the surface by Brownian motion or move by chemotaxis towards the surface in response to the chemical concentration gradient [25]. When at the interface, the cell will form a temporary association with the surface or microbes already present on the surface [26].

After initial association with the surface, a planktonic bacterial cell can dissociate from the surface and resume the planktonic state or become irreversibly attached to the surface. Irreversible attachment involves the production of EPS. EPS serves to bind the cell to the surface and to protect it from the surrounding environment. EPS can be composed of polysaccharides, proteins, nucleic acids, or phospholipids. A common EPS produced by bacterial cells in biofilms is the exopolysaccharide alginate. In biofilm associated cells of Pseudomonas aeruginosa, transcription of $a l g C$, the gene involved in alginate production, was fourfold that in planktonic cells [27]. EPS provide protection to biofilm cells by providing a diffusive barrier to any toxic compounds that could harm the cells as well as a barrier to phagocytes and bacteriocides. The EPS can also represent a barrier to nutrients necessary for cell growth. Cells in the interior of a biofilm often show a much reduced rate of growth and cell division rate may be 
near zero $[26,28]$. The reduced growth rate is itself protective because uptake of toxic substances is also reduced. The presence of the EPS matrix may also serve as a spatial restrictor of cell growth and division.

Water and nutrient diffusion into the interior of a biofilm is highly limited. As biofilms mature, water channels can develop that allow water and nutrient access deeper into the biofilm. These channels partially relieve the diffusion limitation within the biofilm. The architecture of the biofilm develops in response to shear forces. In low shear environments, biofilms can form as thick mushroom-like masses. In high shear environments, biofilms may be flatter or form long strands [29].

A final stage that may occur in the life of a biofilm is reversion of part of the cells to the planktonic state. When cells living in biofilm take up nutrients, they channel much of that energy towards production of EPS rather than to cell growth and division. When nutrients become scarce, cells must escape the EPS matrix or be trapped in an unfavorable environment. Biofilm associated cells are able to produce enzymes capable of breaking down the EPS matrix in times of nutrient starvation. Pseudomonas fluorescens is able to produce an exopolysaccharide lyase under starvation conditions [30]. The enzyme serves not only to break down the polysaccharide matrix allowing cells to find nutrients elsewhere, but the degraded EPS can often be used as a food source for the nutrient deprived cells. In addition to cell detachment due to starvation or nutrient deficiency, there are other detachment processes such as abrasion, shear stress, sloughing and grazing. Providing detailed accounts of these processes is considered beyond the scope of this article.

\section{Factors enhancing biofilm formation}

Several parameters affect how quickly biofilms form and mature, including surface, cellular, and environmental factors. The surface onto which cells will attach has an important impact on biofilm formation. Rough surfaces tend to enhance biofilm formation [31]. Shear forces are lower near a rough surface, and there is a larger surface area to which cells can adhere. Porous materials also work well for biofilm formation. Shear forces are very low inside pores even under conditions where bulk fluid velocity is high. Pores provide a protected environment for cells to attach and grow. Porous materials such as brick and bonechar have been used to immobilize Clostridium cells used in biofilm reactors [22,32]. Biofilm formation also tends to increase with the hydrophobicity of the surface material [28]. Biofilms form much more rapidly on Teflon and other plastics than glass or metal. Possibly this is due to differences in hydrophobicity of the surfaces and ionic charges [28].
The amount of nutrients present in the medium can affect the rate of biofilm formation. Biofilms tend to form more readily in the presence of ample nutrients [33]. One function of the biofilm is to anchor cells in a friendly, nutrient rich environment. Phosphorus is a particularly important nutrient. Cells saturated with phosphate have a higher tendency to flocculate and adhere due to their increased hydrophobicity, while those cells depleted in phosphate are more hydrophilic and less likely to adhere [34].

Temperature can have an effect on biofilm formation. Temperatures at the high end of a culture's growth range can enhance biofilm formation. Depending upon the species involved, high temperature increases the rate of cell growth, EPS production, and surface adhesion, all of which enhance biofilm formation [25].

Cellular factors may affect biofilm formation. A hydrophobic cell will be more able to overcome the initial electrostatic repulsion with the solid surface and adhere more readily. The presence of fimbriae, proteinaceous bacterial appendages high in hydrophobic amino acids, can increase cell surface hydrophobicity [28,35]. Flagellated cells show increased ability to attach to surfaces. Flagellar motility may serve to overcome initial electrostatic surface repulsion.

\section{Calculations and data presentation}

In a continuous process, productivity $\left(\mathrm{gL}^{-1} \mathrm{~h}^{-1}\right)$ is calculated as the product concentration in $\mathrm{gL}^{-1}$ liquid multiplied by the dilution rate $\left(\mathrm{h}^{-1}\right)$. In a batch process, productivity is calculated as the product concentration in $\mathrm{gL}^{-1}$ liquid divided by the fermentation time (h). Specific productivity $\left(\mathrm{h}^{-1}\right)$ is calculated as productivity $\left(\mathrm{gL}^{-1} \mathrm{~h}^{-1}\right)$ divided by cell or protein concentration $\left(\mathrm{gL}^{-1}\right)$. Dilution rate (feed flow per reactor volume per $\mathrm{h}$ ) can be based on total volume of the continuous reactor or void volume. In fully or partially packed bed reactors, void volume is total reactor volume minus the volume occupied by the cell support. For a particular flow rate, dilution rate based on void volume is higher than based on the total reactor volume. In this article, reactor productivities based on both total reactor volume and void volume have been reported as mentioned by the different authors. The reader is advised that it is difficult to correlate/compare the two productivities (based on total reactor volume or void volume) unless void volume fraction (void volume/total volume) is given along with the flow/feed rate. Residence time $(\mathrm{h})$ in the reactor can be calculated by inversing the dilution rate $\left(\mathrm{h}^{-1}\right)$.

\section{Types of biofilm reactors}

Biofilm reactors can be assembled in a number of configurations including batch, continuous stirred tank (CSTR; including agitating continuous reactors, and rotary 
continuous reactors), packed bed (PBR), trickling bed (TBR), fluidized bed (FBR), airlift reactors (ALR), upflow anaerobic sludge blanket (UASB), and expanded bed reactors. The operation of these reactors changes from reactor to reactor. In a batch biofilm reactor, the immobilized cells have to be utilized for repeated batches. However, it is likely that during the late stationary phase of chemical production the culture would experience inhibition thus reducing productivity. Also, in a batch reactor, productivity would be reduced due to downtime necessary to fill and empty the reactor. If the reactor is packed with biofilm particles, some cells may die or become inactive due to lack of feed during emptying and filling of the reactor. As a result, it is viewed that batch reactors are not practical for biofilms.

In a CSTR feed medium is fed to the reactor and product is withdrawn at the same rate as feed. They are stirred using a mechanical device such as impeller. CSTRs cannot be packed with the adsorbent support covered by biofilms as no agitation can be provided in that case. However, they can be used if fibrous bed support is used for adsorption of cells. In that case, cells can grow and form a biofilm on the fibrous bed. In such a case agitation can be provided. This type of system was used for the production of butanol [36] and lactic acid [37] in continuous operation with a constant feed and a constant effluent from the reactor. In some cases, there may be excessive growth on the surface of the fibrous bed, and the cell layers may be sheared off the support. This type of fibrous bed biofilm CSTRs are called as agitating continuous reactors. Another type of CSTRs called rotating CSTRs have same length/ diameter $(\mathrm{L} / \mathrm{D})$ ratio as in CSTRs. The rotating CSTRs are placed horizontally (lengthwise) and are rotated along the horizontal axis.

PBRs are different types of reactors as they are packed with suitable support material followed by inoculation with the culture to form biofilm. The reactor is supplied with a feed that is not deficient in nutrients. Depending on the culture, nutrients, and support, biofilm formation may take a few to several days. Such reactors are usually fed at the bottom, thus getting product at the top of the reactor. However, these reactors are prone to blockade due to excessive cell growth. In C. acetobutylicum/C. beijerinckii biofilm packed bed reactors, reaction rates up to 45 times that of the batch (control) reactors have been obtained $[38,39]$.

TBRs are different from PBRs as they (TBRs) are fed at the top of the reactor thus obtaining product at the bottom. However, in such reactors some of the biofilms may not get sufficient feed thus affecting reactor efficiency/productivity adversely. Also, in gaseous fermentations gas may occupy significant space in the reactor and may form stag- nant pockets. This also may affect the efficiency of the reactor. In anaerobic waste water treatment and acetic acid production, these reactors have been used at large scale successfully.

FBRs have played a successful role in the degradation of toxic phenolic chemicals [40-43] and butanol production $[39,44]$. In these reactors, cell growth occurs around the adsorbent particles. Formation of active biofilms around the particles and accumulation of sufficient biomass in the reactor may take from 2 to 4 weeks. A major advantage in these reactors is that they can be operated for much longer periods than PBR or CSTRs (with fibrous bed). These reactors do not block due to excessive growth. In these reactors butanol production was increased by approximately 40-50 times that of the batch reactors. These reactors have been operated successfully for longer than 4 months in continuous operation (Unpublished data, Qureshi and Maddox).

Airlift reactors contain two concentric tubes, a riser (an inner tube) and a downcomer (an outer tube). In these reactors, mixing is achieved by circulating essentially air at the bottom of the reactor. As a result of force applied by the air (at the bottom of the inner tube), the liquid in the inner tube moves up which then overflows (the inner tube) downward thus creating eddies to mix the liquid. In some of the airlift reactors downcomer is replaced with an external loop to circulate fermentation broth. Such reactors where air is replaced by an anaerobic gas are called gaslift reactors.

Upflow anaerobic sludge blanket (UASB) reactors (contain granular biofilm particles) are used for anaerobic treatment of wastewater/industrial effluents. As the name suggests, the flow in these reactors is in upward direction. At the top of the reactor provisions are made for gas/es to escape and sludge particles to settle to the bottom part of the reactor. Reactor effluent is removed from the top of the reactor. UASB reactor was developed by Lettinga et al. [9]. Fig. 1 shows a schematic diagram of various reactors and biofilm particles.

\section{Biofilm reactors in biological wastewater treatment}

The application of biofilm technology in wastewater treatment originated from the industrial operation of trickling filters in the early 1880s in Wales, Great Britain [45]. Biofilm processes in wastewater treatment can be divided into two categories: namely (1) the fixed-medium systems where the biofilm media are static in the reactors and the biological reactions take place in the biofilm developed on the static media, and (2) the moving-medium systems where the biofilm media are kept continually moving by means of mechanical, hydraulic, or air forces [46]. The moving-medium systems include rotating biological 


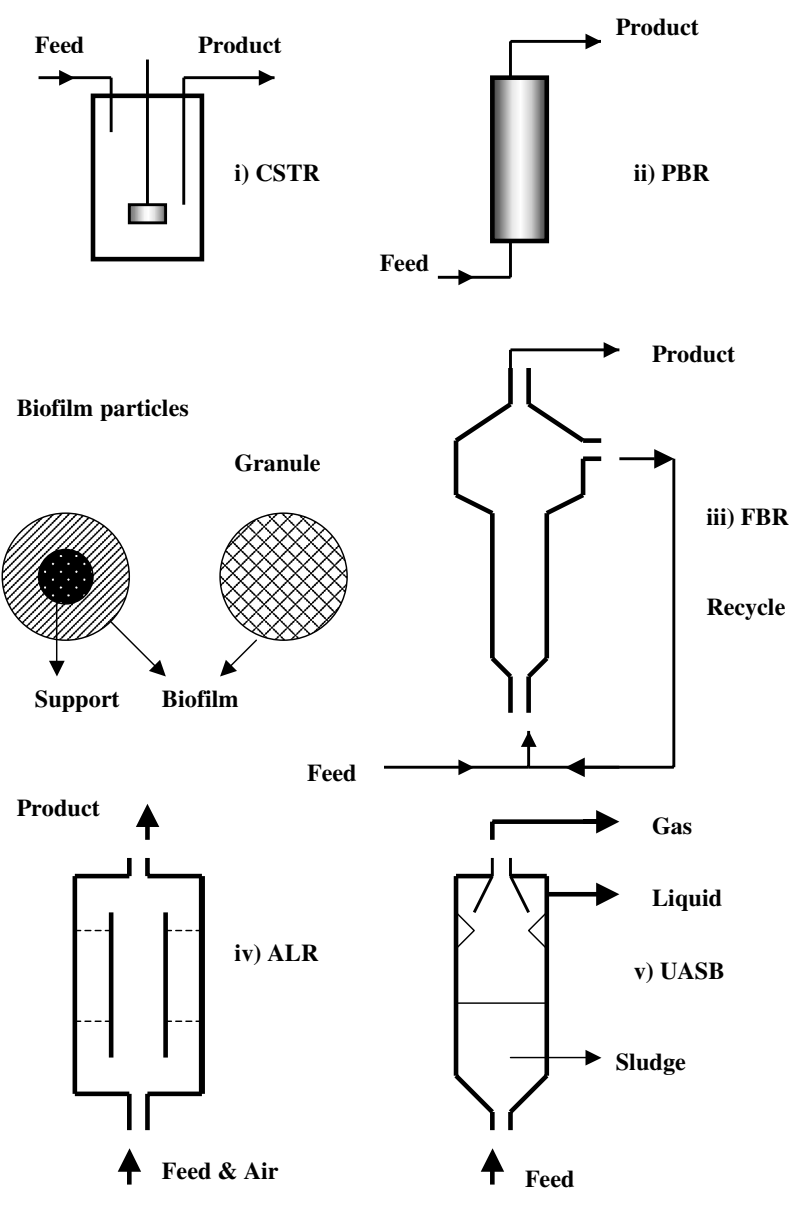

Figure I

Schematic diagrams of various types of biofilm reactors and biofilm particles.

contactors, moving-bed biofilm reactors, vertically moving biofilm reactors, and fluidized bed biofilm reactors; while the fixed-medium systems include trickling filters and biological aerated filters [46]. Rotating biological contactors (RBC) have been widely used in biological treatment of wastewater for reducing chemical oxygen demand (COD)/biological oxygen demand (BOD) $[47,48]$ and nitrification/denitrification purposes $[48,49]$. Rotating biological contactors treat wastewater streams using a thin biofilm of aerobic microorganisms on rotating cylinders or biodiscs. The rate of rotation is selected to provide optimum contact of the waste stream with the biofilm for efficient oxygen transfer and bioactivity.

It should be noted that before a biofilm-based treatment system is to be considered for the treatment of wastewater, it is necessary to determine whether the naturally occurring microorganisms are able to produce biofilms, while simultaneously reducing the COD of the wastewater, or if there is a need to inoculate the reactor with external bacterial strains. The most commonly used rotating biofilm contactor is the rotating biodisc and its various modifications [48]. For the treatment of high strength wastewater, gentle aeration of the liquid phase has been shown to improve the COD reduction of the system by about $40 \%$ [50]. In a related study, Kargi and Eker [48] have shown that a rotating-perforated-tube biofilm reactor is effective in COD removal from synthetic wastewater composed of diluted molasses, urea, $\mathrm{KH}_{2} \mathrm{PO}_{4}$, and $\mathrm{MgSO}_{4}$. The liquid phase in the tank was not aerated, (the total biofilm surface area (A) was $1.34 \mathrm{~m}^{2}$ ), and the rotation speed of the tubes was $5 \mathrm{rpm}[48]$.

In some instances, thermophilic aerobic systems have been employed to biodegrade the wastewaters of high strength, and tremendous COD reductions have been reported in both laboratory and pilot scale experiments $[51,52]$. However, the thermophilic systems exhibited poor bacterial flocculation characteristics due to the dispersed growing microorganisms (no biofilm formation) which made bacterial separation from the treated effluent difficult $[53,54]$.

The fluidized bed biofilm reactors (FBBR; also called as FBR) (in which particles move up and down within the expanded bed in the well defined zone of the reactor) have been used for more than two decades for treating industrial wastewater $[55,56]$. Immobilized bacterial systems configured as fluidized bed biofilm reactors (FBBRs) offer some technical advantages. Since chemical wastes are injected into the recycle, toxic chemicals are immediately diluted, which make the microorganisms more resistant to direct chemical toxicity than many conventional treatment systems. In addition, since FBBRs are usually oxygenated by supplying air into the recycle loop, a high level of microbial activity may be supported with minimal air stripping of volatile chemicals.

Jesis and Owen [57] studied FBBR, and they found that the use of small, fluidized media enabled the FBBR to retain high biomass concentrations and, thereby, operate at significantly reduced hydraulic retention times. In pilot scale operations carried out by Jesis and Owen [57], they reported that when the volatile solid concentrations were between 30,000 to $40,000 \mathrm{mgL}^{-1}$ during denitrification operation, 99\% of influent nitrates could be removed under hydraulic retention times as low as $6 \mathrm{~min}$. In a related study, Rabah and Dahab [56] during their evaluation of the use of fluidized-bed biofilm reactors for nitrate removal concluded that the FBBR system is capable of handling an exceptionally high nitrate nitrogen concentration of $1000 \mathrm{mg}(\mathrm{N}) \mathrm{L}^{-1}$ with very high removal efficiency, up to $99.8 \%$. The authors noted that higher 
Table 2: Productivities of different reactors employed for nitrification and denitrification/during the pretreatment of domestic or industrial wastewater streams.

\begin{tabular}{|c|c|c|c|}
\hline \multirow[t]{2}{*}{ Reactor Type } & \multicolumn{2}{|c|}{ Removal rates (Productivities or specific productivities) } & \multirow[t]{2}{*}{ Reference } \\
\hline & Nitrification & Denitrification & \\
\hline $\begin{array}{l}\text { Activated sludge flocs (Single } \\
\text { reactor) }\end{array}$ & $24 \mu \mathrm{mol} \mathrm{N} \mathrm{g} \mathrm{MLSS-1} \mathrm{h}^{-1}$ & $6 \mu \mathrm{mol} \mathrm{N} \mathrm{g} \mathrm{MLSS}{ }^{-1} \mathrm{~h}^{-1}$ & [65] \\
\hline Sequencing batch & $19 \mathrm{mg} \mathrm{NH} \mathrm{L}^{-1} \mathrm{~h}^{-1}$ & $13.5 \mathrm{mg} \mathrm{N} \mathrm{L-1} \mathrm{h}^{-1}$ & [66] \\
\hline Chemostat (Continuous) & $5.6 \mu \mathrm{mol} \mathrm{NH} \mathrm{h}^{-1} \mathrm{mg}$ protein-1 & $5.6 \mu \mathrm{mol} \mathrm{N} \mathrm{h}^{-1} \mathrm{mg}$ protein ${ }^{-1}$ & [67] \\
\hline Chemostat (Continuous) & $2.6 \mu \mathrm{mol} \mathrm{NH}_{3} \mathrm{~h}^{-1} \mathrm{mg}$ protein -1 & 4.I $\mu \mathrm{mol} \mathrm{N} \mathrm{h}^{-1} \mathrm{mg}$ protein ${ }^{-1}$ & [68] \\
\hline Continuous & $250 \mu \mathrm{mol} \mathrm{NH}{ }_{3} \mathrm{~L}^{-1} \mathrm{~h}^{-1}$ & $400 \mu \mathrm{mol} \mathrm{N} \mathrm{L-1} \mathrm{h}^{-1}$ & [69] \\
\hline
\end{tabular}

MLSS = Mixed liquor suspended solid

denitrification rates can be achieved at relatively low superficial velocities because it is possible to maintain high biomass concentration at lower velocities. However, there is a minimum practical velocity below which agglomeration of media would occur and the process may fail [56]. The efficiency of the FBBR can be up to 10 times greater than that of the activated sludge system and typically occupies $10 \%$ of the space required by stirred tank reactors of similar capacities [56]. Higher biomass concentration in the FBBRs $\left(40,000 \mathrm{mgL}^{-1}\right)$ compared to $3000 \mathrm{mgL}^{-1}$ in the activated sludge have been shown to be the reason for the greater efficiency [58].

Anaerobic treatment of wastewater in fluidized bed reactors is another area that has been studied extensively [59]. In this article, Iza [59] presented theoretical basis for design and operation of a fluidized bed reactor for anaerobic treatment of wastewater. The anaerobic fluidized bed technology offers a number of advantages for treating wastewater including high concentration of biomass attached to the dense support that makes it possible to operate them at high dilution rate without cell washout. In these reactors no plugging, gas hold-up or channeling occurs.

Prior to the development of UASB, interest in anaerobic treatment systems in wastewater treatment was scarce [11]. Interestingly, the development of UASB saw a significant increase in anaerobic removal of various chemicals from the wastewater using these reactors. The examples include anaerobic removal of pentachlorophenol [60], nitrogen removal [61], dechlorination using Dehalospirillum multivorns [62], anaerobic treatment of municipal solid leachate [63], and starch degradation [64]. More studies on this subject have been reviewed in Veeresh et al., [42] (anaerobic treatment of phenol and cresols in UASB reactors). The success of the UASB concept relies on the establishment of a dense sludge bed in the bottom of the reactor which is usually a result of microbial growth and incoming sludge.

Seghezzo et al., [11] reported that in a pilot plant UASB reactor, internal mixing was not optimal for treating sewage $\left(4-20^{\circ} \mathrm{C}\right)$ which produced dead space and hence reduced process efficiency. In order to improve the process efficiency, an adequate influent distribution was sought. The use of effluent recirculation in combination with a taller reactor (a larger height to diameter ratio) resulted in the expanded granular sludge bed (EGSB). Usually expended bed reactors, as opposed to EGSB, have biofilm that is adsorbed onto support particles. An example of expanded bed reactor is that of Tsuno et al., [43] who degraded pentachlorophenol (PCP) in a biological expanded-bed reactor anaerobically. In this reactor the granular activated carbon was used as a support.

Generally, total nitrogen removal from domestic or industrial wastewater streams is achieved in two steps: microbial nitrification of ammonium (aerobic process) followed by denitrification (anaerobic process) or reduction of formed nitrate to nitrogen. This conventional method employs a sequence of aerobic and anoxic processes in order to provide the two different environmental conditions [65]. However, studies have shown that these two important steps can occur simultaneously in one reactor in a process called simultaneous nitrification and denitrification (SND). In SND process, nitrification is restricted to the outer oxic zone of formed microbial flocs, whereas denitrification occurs predominantly in the inner anoxic zones [65]. To test the hypothesis that SND is a physical phenomenon, Pochana and Keller [66] carried out experiments to determine the effect of floc size on SND. Typical floc sizes as measured in their experiments were $50-110 \mu \mathrm{m}$, which is large. Such large floc sizes could create an anoxic zone inside the flocs leading to denitrification. Pochana and Keller [66] concluded that a substantial anoxic mass fraction exists in the center of the 
biomass floc resulting from an oxygen diffusion limitation into the floc. The rates of nitrogen removal (coupled nitrification-denitrification process) or productivities/ specific productivities are shown in Table 2 . The sequencing batch and single activated sludge flocs reactors require some $\mathrm{O}_{2}$ to effect nitrification $\left(\mathrm{NO}_{3}-/ \mathrm{NO}_{2}-\right.$ generation), which is the precursor for denitrification process.

In contrast to previous view that denitrification occurs under anaerobic conditions [67] it (denitrification) has been shown to occur under aerobic conditions with a wide range of bacteria $[68,70]$. Robertson and Kuenen [71] observed that under fully aerobic conditions, Thiosphaera pantotropha carries out the following reactions sequentially and simultaneously, in the presence of a suitable electron donor such as acetate.

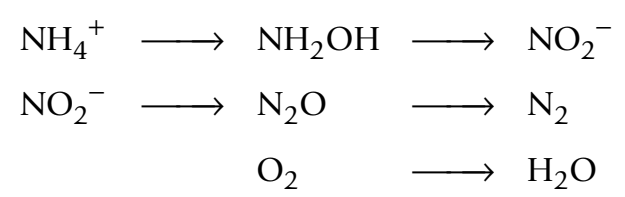

This implies that the organism can convert ammonia into nitrogen gas without intermediary accumulation of nitrite. Investigating the reason why this organism denitrifies under aerobic conditions, Robertson and Kuenen [72] demonstrated that denitrifying enzymes were present even when the organism was growing aerobically without nitrate.

The last decade has witnessed an increased interest in membrane bioreactors for wastewater treatment $[73,74]$. The membrane-aerated biofilm reactor (MABR), whereby the biomass is immobilized on membranes through which oxygen is supplied seems to be the most promising design. Results from studies with MABRs have been reported for the degradation of phenol [40], chlorophenols [41], xylene [75], and ammonia [76]. Stripping losses of volatile organic compounds are minimized, and the oxygen partial pressure in the gas compartment allows easy control of oxygen penetration into the biofilm; the dissolved oxygen gradient across the membrane and the biofilm offers an ideal environment for aerobic strains, and foaming due to surfactants can be prevented [74]. For high strength wastewaters, the possibility of enhanced oxygen penetration depths makes MABRs an attractive option for pollutant biodegradation. However, Casey et al. [74] reported that an excessive growth of biofilm is frequently observed. Therefore, biofilm growth should be controlled when operating this reactor. Although a significant amount of work has been performed on the use of biofilm reactors in wastewater treatment, it is beyond the scope of this article to discuss this work in greater detail.

\section{Biofilms for gas and odor treatment}

Traditionally, industrial waste gases have been treated by physico-chemical methods known as adsorption, scrubbing, condensation, and oxidation processes [77]. Biological waste gas treatment is an attractive and environmentally friendly alternative to physico-chemical methods. Industrial waste gases can serve as energy or carbon sources for microbial metabolism. In addition, inorganic waste gases $\left(\mathrm{H}_{2} \mathrm{~S}, \mathrm{NH}_{3}\right)$ may be treated directly by employing autotrophic microorganisms which have the ability to utilize $\mathrm{CO}_{2}$ as a carbon source for anabolism [78]. Koe and Yang [79] during their evaluation on how to drastically reduce or eliminate the impact of air polluting emissions from wastewater treatment plant suggested that open sources of odorous emissions such as inlet works, primary sedimentation units, aeration tanks, final clarifiers, sludge processing units, and wastewater channels should be covered up and the odorous air be treated before discharging to the ambient atmosphere.

The biofilter, trickling biofilter, and bioscrubber are three major bioreactor designs frequently employed for the treatment of waste gas [78]. A biofilter consists of a filterbed composed of a carrier (sawdust, compost, dry wastewater sludge, etc.) for the active microorganisms and as nutrient source [77]. Biofilters operate by facilitating the transfer of odorous gas from waste air blown through the biofilters into biofilms around particles of biofilter medium in which bacteria, fungi and other microorganisms are immobilized. On the other hand, waste gas treatment in trickling biofilters involves use of a biological filter continuously fed with a liquid medium and packed with a synthetic carrier on which biofilms grow [77]. Trickling biofiltration has been used, especially outside the United States, for removal of odorous waste gases such as $\mathrm{H}_{2} \mathrm{~S}$ [80]. Several species of microorganisms can oxidize hydrogen sulfide to form odorless sulfuric acid. Thiobacillus thiooxidans is capable of oxidizing $\mathrm{H}_{2} \mathrm{~S}$ at low $\mathrm{pH}$ [81]. For effective $\mathrm{H}_{2} \mathrm{~S}$ odor control, an ideal habitat for the growth of sulfide-oxidizing bacteria should be created and competing microbes which normally predominate in aerobic treatment processes should be excluded. De Beer et al., [82] demonstrated that the channels surrounding the cell clusters could increase the supply of oxygen and other nutrients to cells within the biofilm, thus relating structure to function [14]. The biofilm structure appears to be largely determined by the production of slime-like matrix of extracellular polymeric substances, which provide the structural support to the biofilm [14]. The structure of biofilms is largely determined by a number of biological factors such as microorganism growth rate, motility, cell signaling, and the production of extracellular polymeric substances. The physical growth environment may also play a significant role in the determination of the biofilm structure [14], and hence the efficiency. However, 
excessive biofilm development can lead to clogging of the filter-bed of the reactor [78].

Biomass growth and biofilm development can be limited by reducing nutrient supply although this may decrease reactor performance since higher biomass growth shows higher substrate consumption rates [83]. Therefore, it is important to find a balance between excessive biomass growth to prevent biofilter clogging and the odorous gases removal efficiency. Furthermore, waste gases that are characterized by high concentrations of water-soluble pollutants can be treated with bioscrubber. The bioscrubber consists of two reactors. The first reactor is an absorption column where pollutants are absorbed in a liquid phase. The liquid phase goes to the second reactor, which consists of a filter with an activated carbon medium that supports microbial growth. The high bioactivity in the bioscrubber enhances conversion of waste gases into nonhazardous and less odorous compounds. The effluent leaving the bioscrubber can be re-circulated to the absorption column; this technology allows for good gas cleaning when the gaseous pollutants are highly water soluble [77].

Ottengraf [78] reported that the rate of mass transfer of a given compound to be removed or deodorized is determined by the product of the overall mass transfer coefficient, the total contact area in the column, and the average driving force. Therefore, the absorption of a compound will be higher if its concentration in the wastewater is low and its solubility in water is high [78]. The control of operating parameters to the microorganisms in these bioreactors can sometimes be challenging.

\section{Production of industrial chemicals in biofilm reactors \\ Biofilms and biofilm reactors in ethanol production}

Bland et al. [84] produced ethanol in an attached film expanded bed bioreactor of Zymomonas mobilis. The cells of $Z$. mobilis were adsorbed onto vermiculite and the culture formed an active biofilm. Based on the total volume of the reactor, a productivity of $105 \mathrm{gL}^{-1} \mathrm{~h}^{-1}$ was obtained at a dilution rate of $3.6 \mathrm{~h}^{-1}$. Usually, in a control batch or free cell reactor a productivity of $<4 \mathrm{gL}^{-1} \mathrm{~h}^{-1}$ is achieved. The increased/enhanced productivity reported here is due to the formation of active biofilm onto the adsorbent.

Adsorbed cells of Saccharomyces cerevisiae were used in a packed bed continuous bioreactor to produce ethanol from molasses [4]. The cells were immobilized onto a support of natural origin, possibly sugarcane bagasse. It has been reported that the cells were immobilized by natural mode, which is likely to be adsorption. The amount of cells that was adsorbed onto this support was $0.13 \mathrm{gg}^{-1}$ support. In this biofilm reactor, the authors reported a productivity of $28.6 \mathrm{gL}^{-1} \mathrm{~h}^{-1}$ as compared to $3.35 \mathrm{gL}^{-1} \mathrm{~h}^{-1}$ in a free cell continuous process. The dilution rates in the biofilm reactor and free cell continuous system were 0.47 $\mathrm{h}^{-1}$ and $0.65 \mathrm{~h}^{-1}$, respectively. Although immobilized cell reactors (such as this biofilm reactor) are typically operated at higher dilution rates than the free cell continuous reactors, it is not clear why the authors used a lower dilution rate in the biofilm reactor. Since carbon utilization for newly growing cells was reduced, product yield was improved as compared to a batch reactor.

Since ion exchange resins have charge on them, bacterial cells can be adsorbed onto the resins thus forming biofilm layers. This concept was employed by Krug and Daugulis [85] to produce ethanol in high productivity reactors using $Z$. mobilis. To find a suitable adsorbent, 10 ion exchange resins, activated carbon, and ceramic chips were examined. A cationic macroreticular resin was shown to be the most efficient adsorbent to immobilize cells of Zymomonas mobilis. The immobilized cells were used in a continuous column and $100 \mathrm{gL}^{-1}$ glucose was fed to the reactor. As a result of formation of biofilm, the reactor productivity was measured at $135.8 \mathrm{gL}^{-1} \mathrm{~h}^{-1}$ (void volume based productivity, $\left.\mathrm{P}_{\mathrm{dv}}=377.4 \mathrm{gL}^{-1} \mathrm{~h}^{-1}\right)$. The reactor stopped working due to excessive cell growth and plugging after a period of $200 \mathrm{~h}$ of operation.

Other reports on ethanol production in biofilm reactors are those of Kunduru and Pometto [86] and Demirici et al. [8]. Kunduru and Pometto [86] studied ethanol production in continuous reactors using biofilm supports of polypropylene or plastic composite. Employing a culture of $Z$. mobilis and a bacterial support of polypropylene, a staggeringly high productivity of $536 \mathrm{gL}^{-1} \mathrm{~h}^{-1}$ was obtained at a dilution rate of $15.36 \mathrm{~h}^{-1}$. In a control free cell fermentation, a productivity of $5 \mathrm{gL}^{-1} \mathrm{~h}^{-1}$ was obtained at a dilution rate of $0.5 \mathrm{~h}^{-1}$. The biofilm reactor was fed from the top, thus collecting product at the bottom of the reactor.

Kunduru and Pometto [86] used another biofilm reactor of $S$. cerevisiae adsorbed onto a plastic composite support and reported a productivity of $76 \mathrm{gL}^{-1} \mathrm{~h}^{-1}$ at a dilution rate of $2.88 \mathrm{~h}^{-1}$. The reactor productivity in a control reactor was $5 \mathrm{gL}^{-1} \mathrm{~h}^{-1}$ at a dilution rate of $0.5 \mathrm{~h}^{-1}$. Unlike the above biofilm reactor, $S$. cerevisiae biofilm reactor was fed at the bottom, and the product was obtained from the top. It is suggested that for a proper comparison both the reactors should have been fed in the same direction.

In order to enhance biofilm formation, Demirici et al. [8] developed a new support material for the growth of $S$. cerevisiae. A mixture of ground soybean hulls (or oat hulls), complex nutrients, and polypropylene was extruded at high temperature into disks and rings. It is likely that heat sensitive nutrients were inactivated during extrusion. Also, polypropylene film may have covered the nutrients, 
Table 3: A comparison of production of ethanol in adsorbed cell biofilm reactors

\begin{tabular}{|c|c|c|c|c|}
\hline System/Support & Reactor Type & Culture & Productivity $\left[\mathrm{gL}^{-1} \mathbf{h}^{-1}\right]$ & Reference \\
\hline \multicolumn{5}{|l|}{ Biofilm Reactors } \\
\hline Resin & Packed bed & Z. mobilis & I $35.8\left(P_{d T}\right), 377.4\left(P_{d v}\right)$ & {$[85]$} \\
\hline Vermiculite & Packed bedd & Z. mobilis & $105.0\left(\mathrm{P}_{\mathrm{dT}}\right), 210\left(\mathrm{P}_{\mathrm{dv}}\right)$ & [84] \\
\hline Sugarcane bagasse $\mathrm{a}^{\mathrm{a}}$ & Packed bed & S. cerevisiae & $28.6^{\mathrm{b}}$ & {$[4]$} \\
\hline Polypropylene & Packed bede & Z. mobilis & $536^{c}$ & {$[86]$} \\
\hline Plastic composite & Packed bed & S. cerevisiae & $76 \mathrm{c}$ & [86] \\
\hline Cell Recycle & CSTR & Z. mobilis & $200^{\mathrm{b}}$ & {$[88]$} \\
\hline \multicolumn{5}{|c|}{ Batch/Continuous suspended cell (Control) } \\
\hline \multirow[t]{2}{*}{ Continuous } & CSTR & Z. mobilis & $5.0^{\mathrm{b}}$ & [86] \\
\hline & & S. cerevisiae & $5.0^{\mathrm{b}}$ & [86] \\
\hline Continuous & CSTR & S. cerevisiae & $3.35^{\mathrm{b}}$ & [4] \\
\hline
\end{tabular}

a: The support was reported as an adsorbent of natural origin (perhaps sugarcane bagasse)

b: Not reported whether based on total reactor volume or void volume

c: Not reported (possibly based on void volume)

d: Cone shaped

e: Trickling packed bed

$P_{d T}$ - Productivity based on total reactor volume

$P_{d v}$ - Productivity based on reactor void volume

thus making them unavailable to the culture for cell growth. Since no data have been provided on the time period of formation of biofilm or thickness of biofilm, it is difficult to compare this support with other supports.

In a more recent study, Qureshi et al. [87] produced ethanol in a biofilm reactor of genetically engineered Escherichia coli from xylose. The biofilm was formed on clay brick particles, and the reactor was operated continuously for 103 days. The reactor was operated at various flow rates, and reactor productivity was found to be improved compared to a free cell batch process. Table 3 compares ethanol productivities obtained in biofilm reactors of various cultures.

\section{Biofilms and biofilm reactors for butanol production}

Butanol is an important industrial chemical that can be produced from a number of carbohydrates using a number of microbial cultures. Butanol can be used as a fuel and has higher/greater energy content than ethanol. Production of butanol has been investigated in batch, fedbatch, free cell continuous, immobilized cell continuous, and cell recycle continuous reactors [1]. Continuous immobilized cell and cell recycle reactors offer higher productivities than batch and free cell continuous reactors. In addition to achieving a high productivity, a major advantage of immobilized cell technology is that there is no cell washout at high dilution rates.

Adsorption is a technique which does not require any chemicals for cell immobilization and can be easily performed inside the reactor. In order to immobilize cells of Clostridium acetobutylicum, the reactor is packed with an adsorption support followed by inoculation with the culture. The adsorption process varies from 2-3 days to weeks depending upon the culture, support, and the reactor. The culture forms cell layers (biofilm) on the support $[5,6,22]$.

An early report of adsorption of cells of C. acetobutylicum for the production of butanol was that of Forberg and Haggstrom [5]. These authors used beechwood shavings to adsorb cells. The reactor was fed continuously with a glucose solution (and nutrient dosing). Over a period of time, an active biofilm was formed on the wood shavings, and a reactor productivity as high as $1.53 \mathrm{gL}^{-1} \mathrm{~h}^{-1}$ was observed (compared to $<0.1-0.35 \mathrm{gL}^{-1} \mathrm{~h}^{-1}$ in control batch fermentation). This work was followed by experiments examining the production of butanol in adsorbed cell biofilm reactor of $C$. acetobutylicum from whey permeate [6]. It should be noted that biofilm formation on this support was quick, and a reactor productivity of $4.5 \mathrm{gL}^{-1} \mathrm{~h}^{-1}$ was observed, which was superior to any previously reported butanol production system. Following these reports, Welsh et al. [89] investigated the use of a number of adsorption supports for butanol production by C. acetobutylicum in batch and continuous systems. The adsorbents used were coke, kaolinite, and Gel White (a montmorillonite clay). Coke was reported to be superior to other supports for adsorption. A maximum concentration of acetone butanol ethanol (ABE) in the effluent of the reactor was reported to be $12 \mathrm{gL}^{-1}$ at a dilution rate of $0.1 \mathrm{~h}^{-1}$, thus resulting in a productivity of $1.2 \mathrm{gL}^{-1} \mathrm{~h}^{-1}$.

Following above reports, an intensive study was performed on the adsorption of $C$. acetobutylicum on a 
Table 4: Biofilm formation characteristics of Clostridium acetobutylicum/C. beijerinckii onto various supports

\begin{tabular}{|c|c|}
\hline Support & Characteristics \\
\hline Bonechar & $\begin{array}{l}\text { C. acetobutylicum culture } \\
\text { - Adsorption is quick } \\
\text { - Biomass layers (biofilms) become visible in } 3-4 \text { days time } \\
\text { - Between day } 2 \text { and } 4 \text {, the culture produces polysaccharide in high concentrations ( } 2.04 \mathrm{gL}^{-1} \text { broth as compared to } \\
\left.0.95 \mathrm{gL}^{-1} \text { broth from day } 5 \text { to } 30\right) \\
\text { - Once initial layers appear, biomass accumulation is quick } \\
\text { - Desorption does not occur at high dilution rates } \\
\text { - < than } 25 \% \text { cells were desorbed when adsorbed cell particles were agitated at } 200-300 \mathrm{rpm} \text { (in shake flasks on } \\
\text { shaker) at } \mathrm{pH} 2.7 \text { for } 18-24 \mathrm{~h} \text { at } 30^{\circ} \mathrm{C} \\
\text { - During initial stages ( } 2-4 \text { days) the culture produced high concentrations of acids }\left(\sim 6-9 \mathrm{gL}^{-1}\right) \text { followed by becoming } \\
\text { solventogenic } \\
\text { - During solventogenic stages fluctuations in solvent concentrations were less }\end{array}$ \\
\hline Glass beads & $\begin{array}{l}\text { C. acetobutylicum culture } \\
\text { - Biomass accumulation takes much longer than bone char } \\
\text { - During initial stages ( } 2-4 \text { days) higher amount of polysaccharide production does not occur } \\
\text { - Cells do not stick to the support as firmly as onto bonechar } \\
\text { - Reactor produces < } 20 \% \text { solvents as compared to bonechar adsorbed cells } \\
\text { - Reactors are not stable as solvent concentration fluctuates } \\
\text { - Cells can easily be washed off }\end{array}$ \\
\hline $\begin{array}{c}\text { Glass wool, Polypropylene } \\
\text { tow, and stainless steel } \\
\text { wire balls }\end{array}$ & $\begin{array}{l}\text { C. acetobutylicum culture } \\
\text { - <20\% biomass accumulated than in bonechar packed reactor } \\
\text { - Cells do not stick to the support firmly and can be desorbed easily } \\
\text { - Reactors are not stable and poor solventogenesis occurred }\end{array}$ \\
\hline Clay brick (Ref. 38) & $\begin{array}{l}\text { C. beijerinckii culture } \\
\text { - Cells stick firmly as in case of bonechar and reactors were solventogenic }\end{array}$ \\
\hline
\end{tabular}

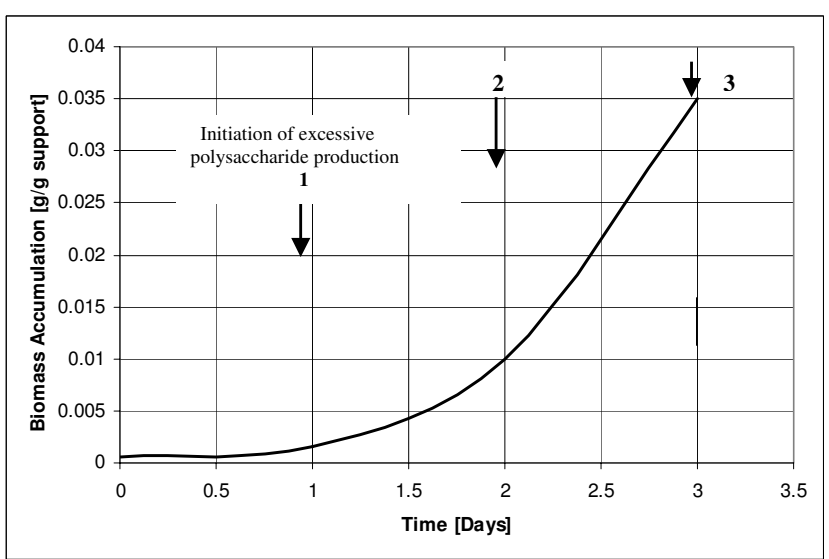

\section{Figure 2}

Production of polysaccharide and accumulation of cell mass during the initial 3 days of adsorption of cells of $C$. acetobutylicum onto bonechar for the production of butanol from whey permeate in a packed bed reactor. I. Initiation of excessive production of polysaccharide; 2 . Maximum growth and attachment starts; 3 . Biofilms become visible and polysaccharide production continues.

number of supports and biofilm formation (Table 4, 5). It has been observed that C. acetobutylicum and C. beijerinckii form visual biofilm layers in 2-4 days (in packed bed reactors), and reactors become productive after $4^{\text {th }}$ day of continuous operation. The techniques of adsorption and reactor operation have been reported previously $[6,38,89]$. It has been observed that not all the supports are suitable for adsorption (Table 4). It has also been observed that during biofilm formation onto bonechar, the culture produces higher concentration of polysaccharide between day 2 and 4. During this period, up to 2.04 $\mathrm{gL}^{-1}$ polysaccharide production was observed as opposed to $0.95 \mathrm{gL}^{-1}$ during day $5-30$ (Fig. 2). As described in the previous section, the cultures that were used for adsorption for butanol production have flagella, which perhaps help bring the cells closer to the surface of support. In addition, charge on the support and cell is likely to aid in initial adsorption or bringing the cells closer to the support surface.

Some supports accumulated more cell concentration ( $C$. acetobutylicum) and were more solventogenic than the others (Table 5). At this stage, we are not aware what makes some supports better than others for biofilm formation and cell accumulation. From some supports it was easier to wash away the cells while from others such as bonechar and clay brick it was more difficult (Table 4). During our studies on butanol production, it was observed that approximately $0.9-1.0 \mathrm{gL}^{-1}$ cells were present in the effluent $[7,90]$ of the reactor. We have demonstrated that the 
Table 5: Production of solvents in packed bed biofilm reactors of $C$. acetobutylicum/C. beijerinckii

\begin{tabular}{|c|c|c|c|c|}
\hline Culture/support & Maximum Solvent $\left[\mathrm{gL}^{-1}\right]$ & $\begin{array}{c}\text { Maximum productivity } \\
{\left[\mathrm{gL}^{-1} \mathrm{~h}^{-1}\right]}\end{array}$ & $\begin{array}{l}\text { Accumulated biomass [gL-1 } \\
\text { reactor vol] }\end{array}$ & $\begin{array}{c}\text { Biomass accumulation [gg-1 } \\
\text { support] }\end{array}$ \\
\hline \multicolumn{5}{|l|}{ C. acetobutylicum } \\
\hline Bonechar & $9.3(0.30)$ & $6.50(1.5)$ & 74.0 & 0.087 \\
\hline Glass beads & $3.0(0.31)$ & $0.93(0.31)$ & 65.0 & 0.044 \\
\hline Glass wool & $3.0(0.10)$ & $0.30(0.10)$ & 3.1 & 0.050 \\
\hline Polypropylene tow & $2.3(0.25)$ & $0.58(0.25)$ & 0.8 & - \\
\hline Stainless steel wire balls & $2.0(0.07)$ & $0.15(0.07)$ & 1.0 & - \\
\hline \multicolumn{5}{|l|}{ C. beijerinckii } \\
\hline Clay brick [Ref 38] & $7.9(2.00)$ & I5.8 (2.00) & 73.7 & 0.093 \\
\hline
\end{tabular}

Numbers in bracket are dilution rates $\left(\mathrm{h}^{-1}\right)$ at which solvent and productivity were obtained

- Values not calculated

cells that are present in the effluent of the reactor are those that grew on the surface of the support, rather than those that grew in liquid medium inside the reactor [90], suggesting that a tremendous amount of activity occurs on the surface of the biofilm in C. beijerinckii/C. acetobutylicum cultures. The thickness of biofilm that is formed in $C$. acetobutylicum or C. beijerinckii cultures can range from few cell layers to as many as 35 or more. Figure 3 shows adsorbed cells and biofilm formed by C. acetobutylicum onto bonechar. Similar observations on biofilm formation were observed for C. beijerinckii [38].

Intensive research has been done on butanol production in various types of reactor systems $[1,39,91,92]$. The biofilm reactor systems that have been used for butanol production include vertical packed bed reactor (PBR), horizontal PBR, compartmentalized reactor, double series reactors, and FBR. The PBRs and FBRs are different in the sense that FBR is started with support $<10 \%$ of its volume while packed beds are filled up to $90 \%$ of their volume. In packed bed reactors, as cell growth occurs, they are often blocked due to excessive cell growth while in FBRs this does not occur. In FBRs, the bed is fluidized either by recycling fermentation broth, using anaerobic gases $\left(\mathrm{N}_{2}\right.$ or $\mathrm{CO}_{2} \& \mathrm{H}_{2}$ in case butanol fermentation) or air (for other aerobic systems). Cell growth occurs all around the support particles and over a period of time the volume of biofilm particles becomes many fold greater than the support particle (Fig. 3, 4). It should be noted that in FBRs cell growth occurs on the particles in spite of broth's high flow rates [44]. In this fluidized bed reactor liquid flow velocity of the order $40-60 \mathrm{~ms}^{-1}$ was maintained. The reader is advised that despite such a high flow velocity, the culture maintains its growth as a biofilm. We have not calculated the shear rate on the biofilm particles. The reactor was used for the production of butanol from whey permeate in continuous operation for $>4$ months (unpublished results - Qureshi \& Maddox). Newly adsorbed C. acetobutylicum cells onto bonechar grow in an exponential manner and accumulation of biomass continues with time. Figure 5 shows a picture of a fluidized bed reactor used for the production of butanol from whey permeate.

Among the various types of reactors used for butanol production, adsorbed cell biofilm reactors (cells adsorbed onto bonechar and clay brick) offered the highest reactor productivities. The reactor productivities that have been achieved in these reactors ranged from 6.5 [39] to 15.8 [38] $\mathrm{gL}^{-1} \mathrm{~h}^{-1}$ (as compared to $0.10-0.38 \mathrm{gL}^{-1} \mathrm{~h}^{-1}$ in batch reactors). Membrane cell reactors also offer high productivities $\left(6.5 \mathrm{gL}^{-1} \mathrm{~h}^{-1}\right)[93,94]$; however, biofilm reactors were superior to these reactors (Table 5). Of the various supports tested, bonechar and clay brick were found to be most suitable, and strong biofilms were formed on these supports. C. acetobutylicum was adsorbed onto bonechar while C. beijerinckii was adsorbed onto clay brick. Attempts were made to desorb the adsorbed cells of C. acetobutylicum. In order to achieve this, $100 \mathrm{~g}$ bonechar with adsorbed cells ( 25 days old reactor) was transferred to a $500 \mathrm{~mL}$ conical flask. The $\mathrm{pH}$ of the solution/reaction mixture was adjusted to 2.7 , and the mixture was placed on a rotary shaker at $250 \mathrm{rpm}$ for 18 to $24 \mathrm{~h}$. After this period $<30 \%$ cells were desorbed from the bonechar.

\section{Biofilms in 2,3-butanediol production}

In an attempt to improve reactor productivity in 2,3butanediol fermentation, Maddox et al. [23] immobilized cells of Klebsiella pneumoniae on to bonechar. The cells of $K$. pneumoniae were adsorbed in a similar manner as $C$. acetobutylicum [6]. During the 2,3-butanediol fermentation, a productivity of $11.7 \mathrm{gL}^{-1} \mathrm{~h}^{-1}$ was obtained, which was the highest reported productivity. Prior to this work Shazer and Speckman [95] reported a productivity of 1.04 $\mathrm{gL}^{-1} \mathrm{~h}^{-1}$ in 2,3-butanediol fermentation using Bacillus 


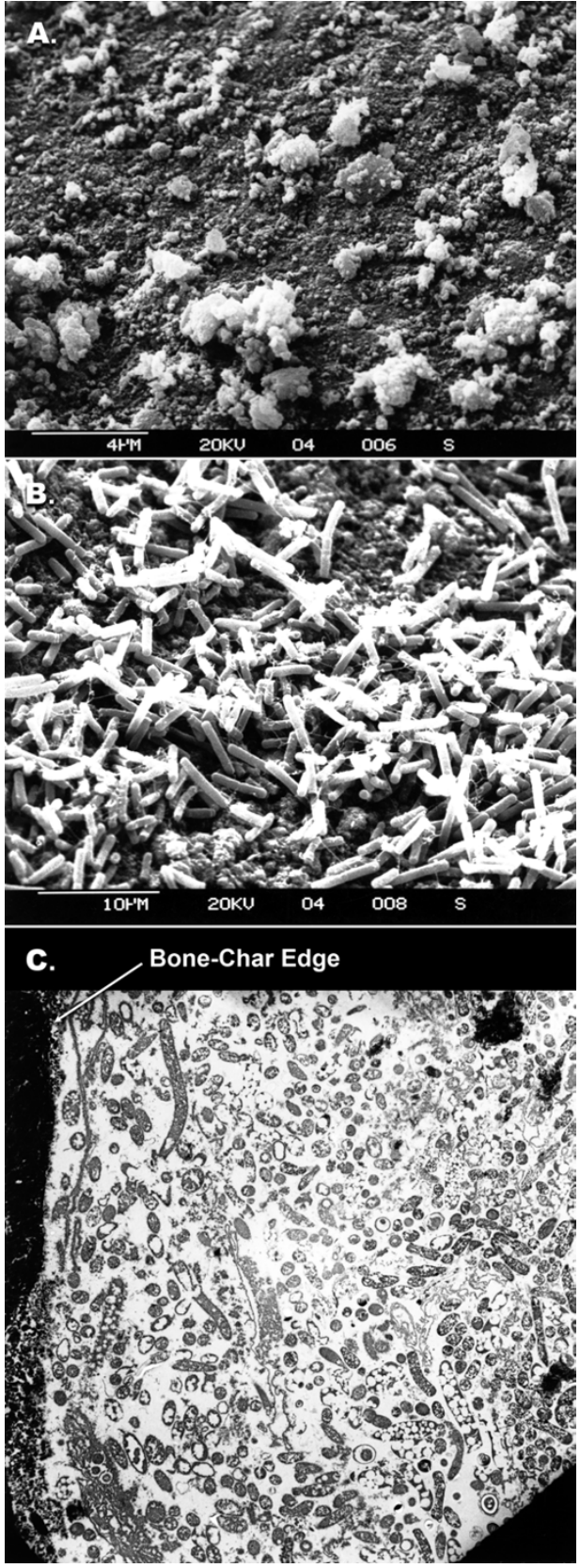

Figure 3

Scanning electron micrograph of adsorbed cells of $C$. acetobutylicum P262 onto bonechar. a) bonechar (magnification 5500); b) adsorbed cells onto bonechar (magnification 2200); c) transmission electron micrograph of adsorbed cells (magnification 2300). Similar figures (3b, c) with different magnification were published previously in the following article: Qureshi N, Paterson AHJ, Maddox IS: Model for continuous production of solvents from whey permeate in a packed bed reactor using cells of Clostridium acetobutylicum immobilized by adsorption onto bonechar. Appl Microbiol Biotechnol 1988, 29:323-328. Figure 3 is reprinted with permission from Springer, Germany (see above article).
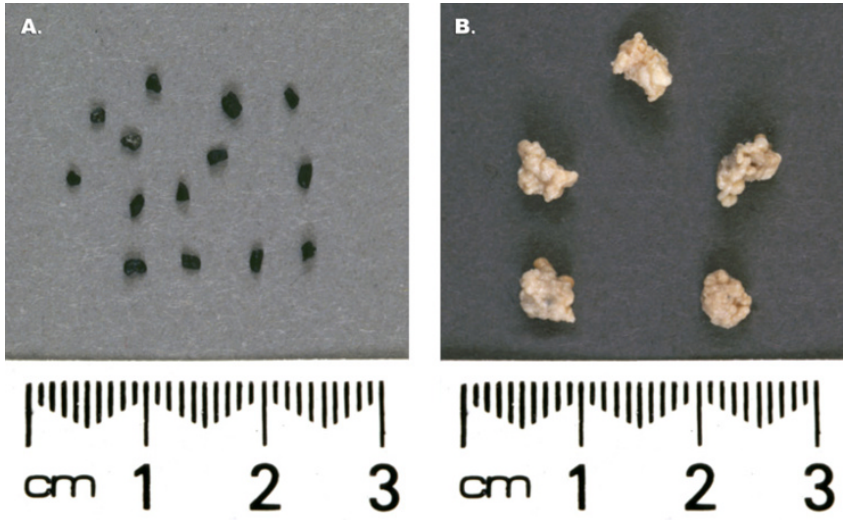

Figure 4

Photographs of biofilm particles of C. acetobutylicum P262 used in a fluidized bed reactor for the production of butanol from whey permeate. A) bonechar particles; B) biofilm particles after growth (bonechar particles are covered with biofilm layers).

polymyxa in a membrane cell reactor. This work clearly demonstrated that bonechar adsorbed cells of K. pneumoniae result in superior productivities. Table 6 compares reactor productivity achieved in biofilm reactor as compared to various other reactor types. It should be noted that although high reactor productivity was obtained in the adsorbed cell reactor, cells did not adsorb on to bonechar as strongly as C. acetobutylicum. Rather, cells were entrapped in between bonechar particles. However, it is anticipated that there were a significant amount of cells sitting on the surface of bonechar as bonechar surface area was large. At the end of fermentation, it was observed that unlike cells of C. acetobutylicum, K. pneumoniae cells were washed away easily. It is not known whether K. pneumoniae cells produce polysaccharide which adds/facilitates adsorption of cells to the surface of bonechar or other surfaces. Even though K. pneumoniae cells do not form firm layers of cells, these reactors are still highly productive.

\section{Production of other chemicals in biofilm reactors}

Other examples of production of industrial chemicals produced in biofilm reactors include acetic acid or vinegar, lactic acid, succinic acid, and fumaric acid. Acetic acid production in trickling bed biofilm reactors is a mature technology and is exercised at the commercial level [13]. In addition to trickling bed biofilm reactor, a submerged process was also developed in late 1940s. The acetic acid is produced by one of the bacteria grouped in the two genera, Gluconobacter and Acetobacter. The species that are used commercially include Acetobacter aceti, A. pasteurianus, and Gluconobacter oxydans. In the trickling bed biofilm reactor (volume $60 \mathrm{~m}^{3}$ ), beechwood shavings are 


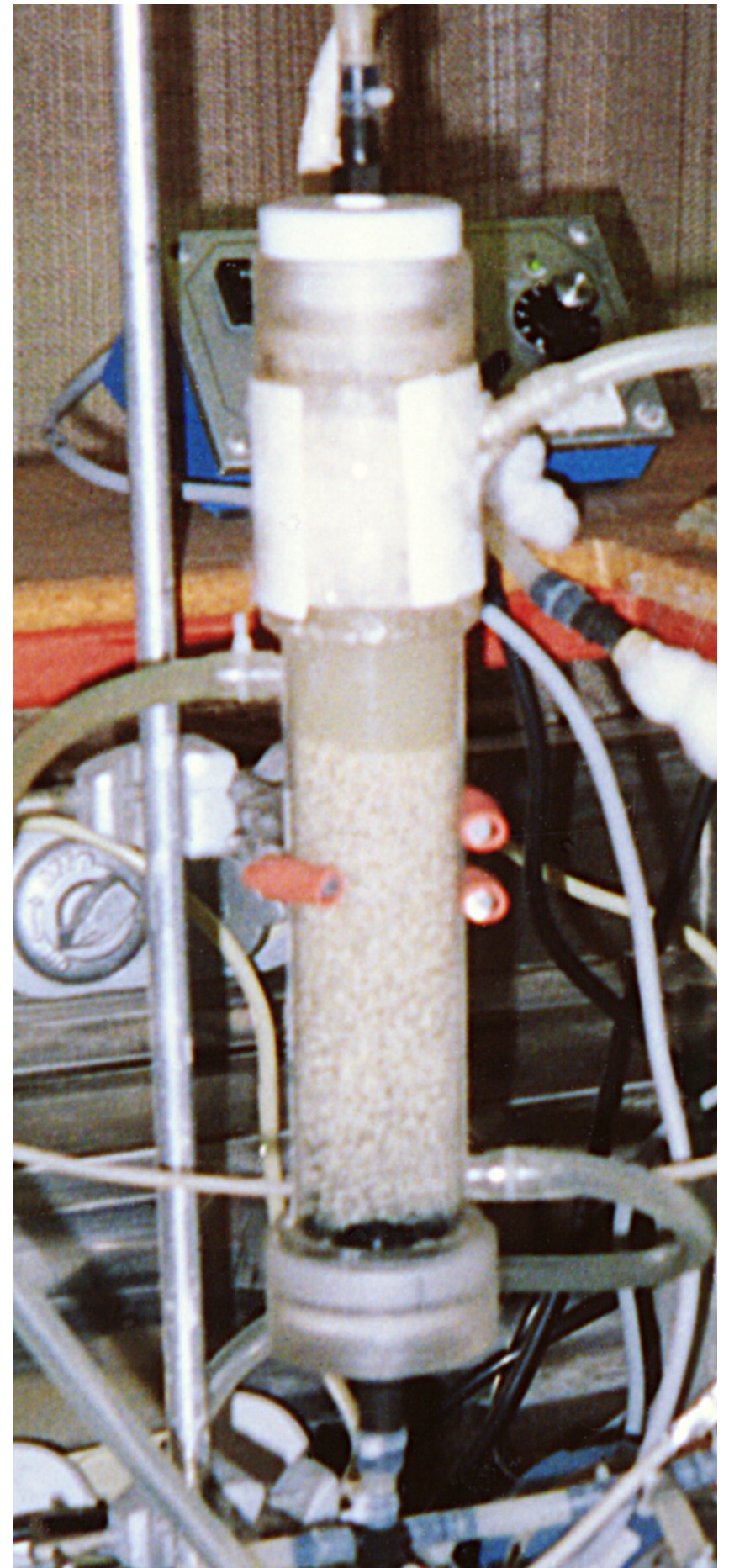

Figure 5

A photograph of a fluidized bed bioreactor (inside volume $450 \mathrm{~cm}^{3}$ ) used to produce butanol from whey permeate using $C$. acetobutylicum P262. packed and the starting material (alcohol solution) is sprayed over the surface. To this solution, initially, nutrients and bacteria are added for growth of biofilm on the beechwood shavings. The liquid trickles to the bottom of the reactor containing acetic acid. In order to increase concentration of acetic acid, the liquid is cooled and pumped back to the top of the reactor. Of the alcohol added, approximately $90 \%$ is converted to acetic acid during the trickling process. Approximately $120 \mathrm{gL}^{-1}$ acetic acid is obtained in $72 \mathrm{~h}$, thus resulting in a productivity of 1.67 $\mathrm{gL}^{-1} \mathrm{~h}^{-1}$.

Production of lactic acid in biofilm reactors is another example of industrial chemical production in such reactors. Demirci et al. [101] evaluated a number of supports for biofilm formation using lactic acid producing cultures. It has been reported that the best biofilms were obtained with Pseudomonas fragi, Streptomyces viridosporus, and Thermoactinomyces vulgaris when used in combination with polypropylene composite chips. The polypropylene composite chips contained polypropylene and $25 \%(\mathrm{w} / \mathrm{w})$ agricultural material. The mixture of these components was extruded through an extruder to form chips of desired dimensions. Following this, a number of reports appeared from the same group on synthesizing, evaluating, and using various supports for biofilm formation and lactic acid production [102-105]. In one of the reports [104], lactic acid was produced in repeated batch cultures in a biofilm reactor. The reactor productivity was improved from 2.78 to $4.26 \mathrm{gL}^{-1} \mathrm{~h}^{-1}$. A maximum lactic acid concentration of $60 \mathrm{gL}^{-1}$ was produced in biofilm reactors where plastic composite support was used for adsorption.

In a study on the production of lactic acid by adsorbed cells of Rhizopus oryzae, the culture was immobilized on a fibrous-bed and used in a bioreactor [37]. The fibrous bed was a sheet of $100 \%$ cotton cloth onto which the culture was adsorbed. In this reactor (fed-batch), a productivity of $2.5 \mathrm{gL}^{-1} \mathrm{~h}^{-1}$ was obtained with a high yield of $90 \%$ and a high product concentration of $127 \mathrm{gL}^{-1}$. Glucose was used as a substrate. When glucose was replaced with cornstarch, yield improved to $100 \%$ and productivity decreased to $1.65 \mathrm{gL}^{-1} \mathrm{~h}^{-1}$. Using starch as a substrate, a product concentration of $126 \mathrm{gL}^{-1}$ was achieved.

Other reports on using cell support for cell growth and lactic acid production are those of Park et al. [106] and Sun et al. [107]. Park et al. [106] used $3 \mathrm{gL}^{-1}$ mineral support (Aid-Plus; ML-50D, Mizusawa Chemical Co., Niigata, Japan) and $5 \mathrm{ppm}$ polyethylene oxide to flocculate the culture and change mycelial morphology from a large pellet to mycelial flocs. Sun et al. [107] immobilized cells of $R$. oryzae in polyurethane foam cubes. There are other reports on the use of immobilized cell technology to produce lactic acid, however, they have not been mentioned 
Table 6: A comparison of 2,3-butanediol productivity in a packed bed biofilm reactor with productivities in other reactor types

\begin{tabular}{|c|c|c|c|c|}
\hline Reactor Type & Culture & Substrate & Productivity $\left[\mathrm{gL}^{-1} \mathrm{~h}^{-1}\right]$ & Reference \\
\hline Biofilm, continuous & K. pneumoniae & Whey permeate & 11.70 & [23] \\
\hline Batch (control) & A. aerogenes & Glucose & 1.10 & [96] \\
\hline Continuous reactor (free cells) & K. pneumoniae & Glucose & 4.25 & [97] \\
\hline Immobilized cell continuous & K. pneumoniae & Whey permeate & 2.30 & [98] \\
\hline Cell recycle, continuous & B. polymyxa & Whey permeate & 1.04 & [95] \\
\hline Cell recycle, continuous & K. pneumoniae & Glucose & 9.84 & [99] \\
\hline Cell recycle, continuous & E. aerogenes & Glucose & 5.40 & {$[100]$} \\
\hline
\end{tabular}

either due to space limitation or studies are not directly related to biofilm formation.

Biofilm reactors have also been used successfully for the production of fumaric acid [108] and mineral ore treatment [13]. In an interesting study, Cao et al. [108] used plastic discs to adsorb cells of $R$. oryzae to produce fumaric acid from glucose. The use of the biofilm reactor resulted in an increase in reactor productivity from $0.9 \mathrm{gL}^{-1} \mathrm{~h}^{-1}$ in a free cell stirred-tank reactor to $4.25 \mathrm{gL}^{-1} \mathrm{~h}^{-1}$ in the biofilm reactor. In the latter reactor, fumaric acid concentration up to $85 \mathrm{gL}^{-1}$ was obtained from $100 \mathrm{gL}^{-1}$ glucose. The fermentation time was shorter and took $20 \mathrm{~h}$ as compared to $72 \mathrm{~h}$ in the free cell reactor.

Succinic acid is a chemical that has been produced in biofilm reactors. The industrial potential for succinic acid fermentation was recognized as early as the late 1970s [109]. Succinic acid $\left(\mathrm{HOOCCH}_{2} \mathrm{CH}_{2} \mathrm{COOH}\right)$ is a dicarboxylic acid, which can be used as a feedstock chemical for the production of high value products such as 1,4-butanediol, tetrahydrofuran, adipic acid, $\gamma$-butyrolactone, and $n$ methylpyrrolidone [109] for applications in agriculture, food, medicine, plastics, cosmetics, and textiles. In a recent study on succinic acid production using Actinobacillus succinogenes, Urbance et al. [110] employed the customized plastic composite support (PCS) [111] and 20 other different PCS blends with and without mineral salt additions and evaluated 20 simulated repeated-batch fermentations using $\mathrm{MgCO}_{3}$ for $\mathrm{pH}$ control and $\mathrm{CO}_{2}$ supply. The customized plastic composite support (PCS) blends were screened for biofilm formation and succinic acid production. Succinic acid concentrations, percentage yield of succinic acid, and biofilm formation for each PCS blend were determined and no correlation between biofilm formation and succinic acid production was observed. However, the customized PCS blend for A. succinogenes in succinic acid production demonstrated $70 \%$ yields for succinic acid compared to $64 \%$ yield for suspended cell bioreactor [110]. Table 7 shows production of various chemicals in biofilm reactors.

\section{Enhanced rates of production of chemicals in biofilm reactors Length of operation of biofilm reactors}

Packed bed reactors often block due to excessive cell growth. It should be noted that reactor blockage depends on a number of factors including cell growth rate, packing density of the support, and supply of nutrients. This type of reactor has been operated ranging from 2 weeks to 3 months. Tyagi and Ghose [4] used a packed bed biofilm reactor of $S$. cerevisiae for a period of 35 days, while Qureshi et al. [87] used a packed bed biofilm reactor of $E$. coli for a period of 103 days for ethanol production in continuous operation. However, it was observed that packed bed biofilm reactors of C. acetobutylicum/C. beijerinckii blocked sooner than 103 days due to enhanced cell growth of these cultures. In order to prolong life of the reactor, feed media deficient in nutrients should be attempted as used by Qureshi \& Maddox [6] and Qureshi et al. [90]. It has been observed that this type of reactor blocks at the bottom where fresh feed allows excessive cell growth. In the upper part of the reactor, minimal growth occurs due to product inhibition as in case of butanol and ethanol production. In such cases, inverting the reactor can prolong life of reactor. In addition to the reactor blockage due to excessive growth, influent to the reactor plays an important role in prolonging life of the reactor. Reactor feed may contain suspended and particulate solids, in particular with wastewater influents, which may block the reactor. It is suggested that such influents be filtered or centrifuged to remove suspended and particulate solids to prolong reactor's life.

Fluidized bed reactors do not block due to excessive growth and they can be operated for a long period of time ( $>4$ months). It is also viewed that UASB and EGSB can be operated for long periods. Table 8 shows length of operation of different reactors for the production of various chemicals, their productivities and dilution rates. Biofilm reactors are highly productive as compared to other reactor systems. The reader is advised to refer to the production of various chemicals in biofilm reactor 
Table 7: Production of various other chemicals in biofilm reactors

\begin{tabular}{|c|c|c|c|}
\hline Product/Reactor Type & Adsorption support & Productivity $\left[\mathrm{gL}^{-1} \mathrm{~h}^{-1}\right]$ & Reference \\
\hline \multicolumn{4}{|l|}{ Acetic acid } \\
\hline Trickling bed biofilm reactor & Beechwood shavings & $1.67(120)$ & [13] \\
\hline \multicolumn{4}{|l|}{ Lactic acid } \\
\hline Agitating continuous reactor & Fibrous bed (cloth) & $2.5(126)$ & [37] \\
\hline \multicolumn{4}{|l|}{ Fumaric acid } \\
\hline Rotary continuous reactor & Plastic discs & $4.25(85)$ & {$[108]$} \\
\hline Strirred-tank (control) & None & 0.91 & {$[108]$} \\
\hline \multicolumn{4}{|l|}{ Succinic acid } \\
\hline Repeated batch fermentations & Plastic discs & - & {$[110]$} \\
\hline
\end{tabular}

Numbers in bracket - product concentration in $\mathrm{gL}^{-1}$

systems (in this article) to be able to compare their production rates with the other non-biofilm reactor systems.

\section{Barriers in biofilm reactors}

In adsorbed cell biofilm reactors of C. acetobutylicum, it was identified that there were four different cell types: growing cells, butanol producing cells, dead cells, and inactive cells (non-growing, nutrient requiring) [7]. Cells that were involved in butanol production were only a fraction of the total cells. For example, the concentration of cells in the reactor was approximately $74 \mathrm{gL}^{-1}$, while the butanol producing cell mass was $<10 \%$ of the total cells. The amount of dead cells or spores occupied most of the space in the reactor. It is viewed that if sporulation is blocked, the reactor productivity could be increased by many fold. This would improve the process economics of butanol production in biofilm reactors. At this stage we are not aware if this is applicable to the other organisms such as ethanol, 2,3-butanediol, succinic, acetic (vinegar), lactic and fumaric acid producers. It is suggested that this be investigated for the cultures that produce these chemicals. In UASB internal mixing is not optimal which reduces efficiency of the reactor [11]. This produces dead space in the reactor. For that reason expanded granular sludge bed (EGSB) are investigated [11].

\section{Diffusion limitations}

Usually biofilms contain multiple layers of cells. The thickness of the biofilm may vary from a few to many $\mu \mathrm{m}$. An increase in the biofilm particle diameter affects hydrodynamic conditions in the reactor including fluidization characteristics etc [59]. In order to measure the thickness of biofilm in C. acetobutylicum culture (PBR), an electron transmission micrograph was taken of a particle and it was identified that the biofilm was made up of $>30$ cell layers (Fig. 3c). In order for the cells to be active and be taking part in the reaction, nutrients and substrate must diffuse/ penetrate to the inner layers of cells. However, it is likely that the nutrients and substrate are used up by the outer cell layers before they reach the innermost cell layers. If this is true, the innermost layers would neither survive nor take part in the reaction. Another example where the thickness of cell layers is an important consideration is bioparticles in a fluidized bed reactor. In these reactors the size of the bioparticles is much bigger than the bioparticle in PBR and cell layers are $>>30$. Accumulation of so many cell layers adds to the diffusion resistance to the substrate and nutrients. In order to keep the diffusion resistance to a minimum possible level, the size of the bioparticle should be kept to a minimum level while still keeping productivity of the reactor high. This should increase the rate of reaction and benefit the process economics.

In aerobic biofilm processes, such as oxidative degradation of toxic chemicals and production of acetic acid in trickling bed biofilm reactors, a constant supply of oxygen is essential. The oxygen should be dissolved in the liquid and be transported to the innermost layers. The penetration depth of oxygen should be $100 \%$ of the biofilm thickness. If the bioparticle size is large, then the inner layers would be starved of oxygen and the cells would die thus decreasing the conversion efficiency of the process. Supply of oxygen rather than air to the reactor would improve diffusion of oxygen to the inner layers; however, it would add to the cost of the process. Hence, size of the biofilms should also be kept to low to keep the reactor productive. In aerobic wastewater biofilm reactors oxygen is an important substrate/nutrient [12]. For anaerobic systems oxygen is toxic.

In addition to the above limitations, an additional limitation comes from the toxicity of product/s itself. Many of the fermentation products are toxic to the cells that produce them. Examples of such toxic products are those that have been described in the earlier section of this article. Butanol is toxic to the cells of C. acetobutylicum/C. beijerinckii and at higher concentrations it kills the cells. In the biofilm layers, the diffused substrate is converted to the 
Table 8: Length of operation of various biofilm reactors used for the production of different chemicals

\begin{tabular}{|c|c|c|c|c|}
\hline Chemical Produced & Reactor Type & $\begin{array}{c}\text { Length of operation } \\
\text { [Days] }\end{array}$ & $\begin{array}{c}\text { Dilution rate }\left[\mathrm{h}^{-1}\right] \\
\text { (Productivity }\left[\mathrm{gL}^{-1} \mathbf{h}^{-1}\right)\end{array}$ & Reference \\
\hline \multirow[t]{2}{*}{ Butanol } & Packed bed & 61 days & $0.30-1.00(0.98-4.10)$ & [6] \\
\hline & Fluidized bed & $>4$ months & $0.33-1.37(1.65-5.10)$ & Unpublished data \\
\hline Lactic acid & Various reactors & $\begin{array}{c}\text { Reviewed in ref } 79 \text { (Table } \\
\text { I) }\end{array}$ & -- & [37] \\
\hline \multirow[t]{3}{*}{ Ethanol } & Packed bed & 35 days & $0.12-0.48(7.80-28.60)$ & [4] \\
\hline & Packed bed & 103 days & $0.04-0.12(1.10-2.58)$ & [87] \\
\hline & Packed bed & 60 days & $0.50-5.76(5.00-74.88)$ & [86] \\
\hline
\end{tabular}

I Qureshi \& Maddox

- Not reported

products such as butanol. It is not known how quickly the produced butanol diffuses out of the cell layers. It is conceivable that accumulated butanol or other chemicals kill the cells before it is diffused out. It is also likely that a combination of nutrient deficiency and toxicity affects the cells more adversely.

\section{Industrial/pilot-plant level biofilm reactors Wastewater treatment}

Biofilm reactors have successfully been used in wastewater treatment [9-12,43,59,61]. In these industrial biofilm reactors cell mass concentration as high as $30-40 \mathrm{gL}^{-1}$ could be maintained $[12,58]$. As a result of superior efficiency, biofilm reactors are being used throughout the world with a number of full scale application for industrial and wastewater treatment. Examples of these reactors operating in The Netherlands and Brazil are shown in Fig. 6.

\section{Acetic acid/vinegar production}

Commercial production of acetic acid or vinegar using biofilm reactors has been exercised for many years. Production of these chemicals has been reported by Crueger \& Crueger [13]. Large biofilm fermentors of size up to $60,000 \mathrm{~L}$ have been used. Often beechwood shavings are used as a support for biofilm formation. For this system, trickling bed reactors have been used with an exit product concentration up to $120 \mathrm{gL}^{-1}$ and a productivity of $1.67 \mathrm{gL}^{-}$ ${ }^{1} \mathrm{~h}^{-1}$. A description of the process has been given in previous sections.

\section{Butanol production}

Butanol production in biofilm reactors has been practiced in numerous types of reactors at laboratory scale $[6,38,39,44]$ with superior productivity to batch, fedbatch, and free cell continuous fermentations. Two of the most prominently used reactors are packed bed and fluidized bed reactors. In these reactors, productivities of the order of 4.5-15.8 $\mathrm{gL}^{-1} \mathrm{~h}^{-1}$ have been achieved as compared to productivities of $0.10-0.38 \mathrm{gL}^{-1} \mathrm{~h}^{-1}$ in batch reactors. Given the scenario of increasing petroleum prices, it is suggested that fluidized bed reactors be scaled up to pilot plant level in view to further commercialize this fermentation.

\section{Other processes}

Production of other industrial chemicals such as lactic acid and 2,3-butanediol should be exercised at pilot plant level. Nicolella et al. [12] reported that biofilm reactors are in operation at industrial scale throughout the world. Use of biofilm reactors is anticipated to be economical for the production of these industrial chemicals.

\section{Future directions \& conclusions}

A comparison of biofilm reactors with other reactor systems suggests that biofilm reactors are simple and offer higher productivities than other reactor systems. In biofilm reactors, cells can be adsorbed within the reactor without the use of any chemicals, and the reactors can be operated for long period of times. This would help in reducing the process cost. These reactors are already in use for wastewater treatment and acetic acid/vinegar production by fermentation. It is clear that their use at bench scale has been consistently increasing for the production of various other chemicals. As productivities in these simple biofilm reactors are high, their full potential should be employed for biotechnological/biological conversion processes. For further reading on biofilms and their formation, the reader is referred to the comprehensive articles published by Costerton et al., [112] and O'Toole et al., [113].

\section{Authors' contributions}

NQ would like not to mention the contributions made by individual authors. However, it is stated that all the authors made significant contributions to deserve to be contributing authors of this comprehensive article on "Biofilm Reactors." 

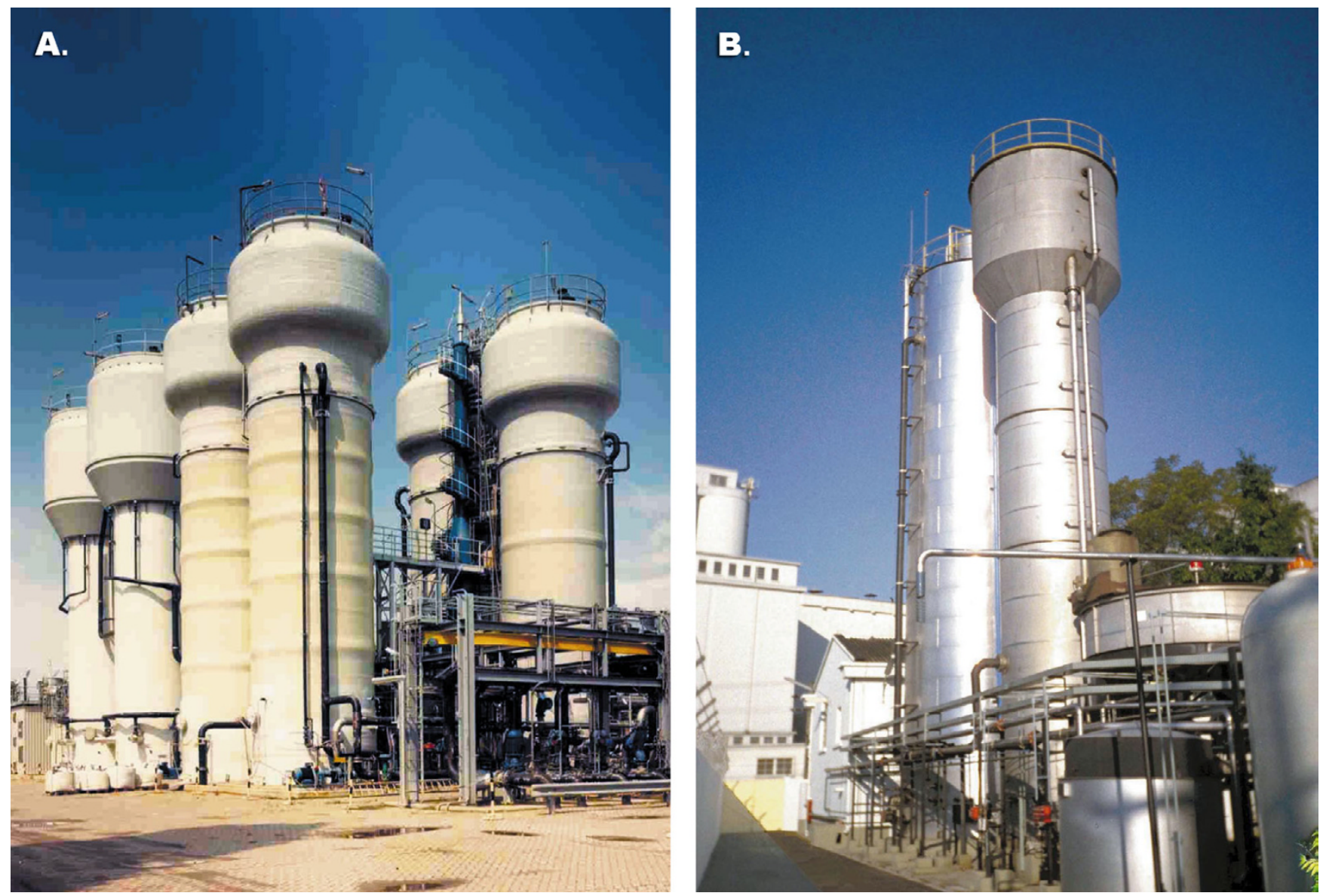

Figure 6

Full scale biofilm reactors: (a) biothane biofilm airlift suspension and expanded granular sludge blanket (Biobed) reactors at Gist Brocades, Delft (The Netherlands); (b) Pagues CIRCOX (foreground; $140 \mathrm{~m}^{3}$ ) and internal circulation (background; 385 $\mathrm{m}^{3}$ ) reactors at a brewery in Brazil. Reprinted from "Nicolella C, van Loosdrecht MCM, Heijnen SJ: Particle-based biofilm reactor technology. Trends in Biotechnology 2000, I 8: 312-320, with permission from Elsevier, United Kingdom.

\section{Note}

** Mention of trade names of commercial products in this article is solely for the purpose of providing scientific information and does not imply recommendation or endorsement by the United States Department of Agriculture.

\section{Acknowledgements}

N. Qureshi would like to thank Michael A Cotta (United States Department of Agriculture, National Center for Agricultural Utilization Research [USDA/NCAUR], Peoria, IL) for his encouragement during the preparation of this article and reading the manuscript critically. NQ is grateful to Professor Eberhard Morgenroth (Department of Civil and Environmental Engineering, University of Illinois, Urbana, IL) for his help with UASB reactors. Help from Christopher Skory (USDA/NCAUR) is also acknowledged. NQ would like to thank Holly Brining and Mark Maroon for their help during the preparation of this manuscript and Don Fraser for photographic/scanning work. NQ \& ISM are grateful to Mr. Doug Hopcroft (AgResearch Ltd.,
Palmerston North, New Zealand; formerly known as Department of Scientific and Industrial Research [D.S.I.R; Biotechnology Division]) for performing the electron microscopy.

\section{References}

I. Maddox IS: The acetone butanol ethanol fermentation: recent progress in technology. Biotechnol Genetic Eng Reviews 1989, 7:190-220.

2. Qureshi N, Blaschek HP: Evaluation of recent advances in butanol fermentation, upstream, and downstream processing. Bioproc Biosys Eng 200I, 24:21 9-226.

3. Mehaia MA, Cheryan M: Ethanol production in a hollow fiber bioreactor using Saccharomyces cerevisiae. Appl Microbiol Biotechnol 1984, 20:100-104.

4. Tyagi RD, Ghose TK: Studies on immobilized Saccharomyces cerevisiae. I. Analysis of continuous rapid ethanol fermentation in immobilized cell reactor. Biotechnol Bioeng 1982, 24:78I-795

5. Forberg C, Haggstrom L: Control of cell adhesion and activity during continuous production of acetone and butanol with adsorbed cells. Enz Microbial Technol 1985, 7:230-234.

6. Qureshi N, Maddox IS: Continuous solvent production from whey permeate using cells of Clostridium acetobutylicum 
immobilized by adsorption onto bonechar. Enz Microbial Technol 1987, 9:668-67।

7. Qureshi N, Paterson AHJ, Maddox IS: Model for continuous production of solvents from whey permeate in a packed bed reactor using cells of Clostridium acetobutylicum immobilized by adsorption onto bonechar. Appl Microbiol Biotechnol 1988, 29:323-328.

8. Demirci A, Pometto AL III, Ho KLG: Ethanol production by Saccharomyces cerevisiae in biofilm reactors. J Ind Microbiol Biotechnol 1997, 19:299-304

9. Lettinga G, van Nelsen AFM, Hobma SW, de Zeeuw W, Klapwijk A: Use of the upflow sludge blanket (USB) reactor concept for biological wastewater treatment, especially for anaerobic treatment. Biotechnol Bioeng 1980, 22:699-734.

10. Lettinga G, Roersma R, Grin P: Anaerobic treatment of raw domestic sewage at ambient temperature using a granular bed UASB reactor. Biotechnol Bioeng 1983, 25: I70|-I723.

II. Seghezzo L, Zeeman G, van Lier JB, Hamelers HVM, Lettinga G: A review: The anaerobic treatment of sewage in UASB and EGSB reactors. Bioresource Technol 1998, 65:175-190.

12. Nicolella C, van Loosdrecht MCM, Heijnen SJ: Particle-based biofilm reactor technology. Trends in Biotechnol (TIBTECH) 2000, 18:312-320.

13. Crueger W, Crueger C: Organic acids. In "Biotechnology" A textbook of industrial microbiology Sinauer Associates, Inc., Sunderland. MA; 1989.

14. Stoodley P, Sauer K, Davies DG, Costerton JW: Biofilms as complex differentiated communities. Annu Rev Microbiol 2002. 56:187-209.

15. Costerton JW, Stewart PS, Greenburg EP: Bacterial biofilms: a common cause of persistent infections. Science 1999, 284(54|8): |3|8-|322.

16. Mortensen KP, Conley SN: Film fill fouling in counterflow cooling towers: mechanisms and design. CTI ] 1994, I5:10-25.

17. McDonogh R, Schaule G, Flemming HC: The permeability of biofouling layers on membranes. J Membr Sci 1994, 87:199-217.

18. Carpentier B, Cerf O: Biofilm and their consequences with particular reference to hygiene in the food industry. J Appl Bacteriol I993, 75:499-5II.

19. Taras M, Hakansson K, Guieysse B: Continuous acetonitrile degradation in packed-bed bioreactor. Appl Microbiol Biotechnol 2005, 66:567-574

20. Hall ER: Biofilm reactors in anaerobic wastewater treatment. Biotech Adv 1987, 5:257-269.

21. Meyer A, Wallis FM: Development of microbial biofilms on various surfaces for the treatment of heavy metal containing effluents. Biotechnol Tech 1997, I I ( I 2):859-863.

22. Qureshi N, Maddox IS: Novel bioreactors for the ABE fermentation using cells of Clostridium acetobutylicum immobilized by adsorption onto bonechar. In Fermentation technologies: Industrial applications Edited by: Yu PL. London: Elsevier Appl Sci Publ; 1990.

23. Maddox IS, Qureshi N, McQueen J: Continuous production of 2,3-butanediol from whey permeate using cells of Klebsiella pneumoniae immobilized on to bonechar. New Zealand J Dairy Sci Technol 1988, 23:127-132.

24. Sponza DT: Anaerobic granule formation and tetrachloroethylene (TCE) removal in an upflow anaerobic sludge blanket (UASB) reactor. Enz Microbial Technol 2001, 29:417-427.

25. Annachhatre AP, Bhamidimarri SMR: Microbial attachment and growth in fixed-film reactors: process startup considerations. Biotech Adv 1992, 10:69-91.

26. Watnick P, Kolter R: Biofilm, City of microbes. J Bacteriol 2000 , I 82(10):2675-2679.

27. Davies DG, Chakrabarty AM, Geesey GG: Exopolysaccharide production in biofilms: substratum activation of alginate gene expression by Pseudomonas aeruginosa. Appl Environ Microbiol 1993, 59:1181-1186.

28. Donlan RM, Costerton JW: Biofilms: survival mechanisms of clinically relevant microorganisms. Clin Microbiol Rev 2002, I5(2):167-193.

29. Costerton JW, Lewandowski Z, Caldwell DE, Korber DR, LappinScott HM. Microbial biofilms. Annu Rev Microbiol 1995, 49:7। I-745.

30. Allison DG, Ruiz B, Sanjose C, Jaspe C, Gilbert P: Extracellular products as mediators of the formation and detachment of Pseudomonas fluorescens biofilms. FEMS Microbial Lett 1998, 167:179-184.
31. Characklis WG, McFeters GA, Marshall KC: Physiological ecology in biofilm systems. In Biofilms Volume 37. Edited by: Characklis WG, Marshall KC. New York: John Wiley and Sons; 1990:67-72.

32. Qureshi N, Karcher P, Cotta M, Blaschek HP: High-productivity continuous biofilm reactor for butanol production. Appl Biochem Biotechnol 2004, I | 3- | | 6:7| 3-72I.

33. Cowan MM, Warren TM, Fletcher M: Mixed species colonization of solid surfaces in laboratory biofilms. Biofouling 1991, 3:23-34.

34. Bücks J, Mozes N, Wandrey C, Rouxhet PG: Cell adsorption control by culture conditions. Appl Microbiol Biotechnol 1988, 29:119-128.

35. Donlan RM: Biofilms: microbial life on surfaces. Emerg $\ln f$ Dis 1992, 8(9):88|-890.

36. Huang WC, Ramey DE, Yang ST: Continuous production of butanol by Clostridium acetobutylicum immobilized in a fibrous bed bioreactor. Appl Biochem Biotechnol 2004, I I3:887-898.

37. Tay A, Yang ST: Production of L-(+)-lactic acid from glucose and starch by immobilized cells of Rhizopus oryzae in a rotating fibrous bed bioreactor. Biotechnol Bioeng 2002, 80:1-12.

38. Qureshi N, Schripsema J, Lienhardt J, Blaschek HP: Continuous solvent production by Clostridium beijerinckii BAIOI immobilized by adsorption onto brick. World J Microbiol Biotechnol 2000, 16:377-382.

39. Qureshi N, Maddox IS: Reactor design for the ABE fermentation using cells of Clostridium acetobutylicum immobilized by adsorption onto bonechar. Bioprocess Eng 1988, 3:69-72.

40. Woolard CR, Irvine RL: Biological treatment of hypersaline wastewater by a biofilm of halophilic bacteria. Water Environ Res 1994, 66:230-235.

41. Wobus A, Ulrich S, Roske I: Degradation of chlorophenols by biofilms on semi-permeable membranes in two types of fixed bed reactors. Water Sci Technol 1995, 32:205-2 I2.

42. Veeresh GS, Kumar P, Mehrotra I: Treatment of phenol and cresols in upflow anaerobic sludge blanket (UASB) process: A review. Water Research 2005, 39:154-170.

43. Tsuno H, Kawamura M, Somiya I: Anaerobic degradation of pentachlorophenol (PCP) in biological expanded-bed reactor. Water Sci Technol 1996, 34(5-6):335-344.

44. Qureshi N, Maddox IS: Integration of continuous production and recovery of solvents from whey permeate: use of immobilized cells of Clostridium acetobutylicum in fluidized bed bioreactor coupled with gas stripping. Bioprocess Engineering $|99|$, 6:63-69.

45. Lazarova V, Manem J: Innovative biofilm treatment technologies for water and wastewater treatment. In Biofilm II: Process analysis and applications Edited by: Bryers JD. New York: Wiley-Liss Press; 2000:159-206.

46. Rodgers $M$, Zhan XM: Moving-medium biofilm reactors. Rev Environ Sci Bio/Technol 2003, 2:2 I3-224.

47. Kargi F, Dincer AR: Salt inhibition effects in biological treatment of saline wastewater in RBC. J Environ Eng 1999, | 25:966-97|

48. Kargi F, Eker S: Rotating-perforated-tubes biofilm reactor for high-strength wastewater treatment. J Environ Eng 200I, 1 27:959-963.

49. Gönec $E$, Harremoes P: Nitrification in rotating disc systems. Water Res 1985, 19:119-127.

50. Kargi F, Uygur A: Effect of liquid phase aeration on performance of rotating biodisc contactor treating saline wastewater. Environ Technol 1997, 1 8:623-630.

5I. Lapara TM, Knopka A, Nakatsu CH, Alleman JE: Thermophilic aerobic treatment of a synthetic wastewater in a membranecoupled bioreactor. J Ind Microbiol Biotechnol 200I, 26:203-209.

52. Vogelaar JCT, Bouwhuis E, Klapwijk A, Spanjers H, van Lier JB: Mesophilic and thermophilic activated sludge post-treatment of paper mill process water. Water Res 2002, 36:1869-1879.

53. Tripathi CS, Allen DG: Comparison of mesophilic and thermophilic aerobic biological treatment in sequencing batch reactors treating bleached Kraft pulp mill effluent. Water Res 1999, 33:836-846.

54. Quesnel D, Nakhla G: Utilization of an activated sludge for the improvement of an existing thermophilic wastewater treatment system. Environ Eng 2005, 13 1:570-578.

55. Jeris JS, Owen RW, Hickey R, Flood F: Biological fluidized-bed treatment for BOD and nitrogen removal. I Water Pollut Control Fed 1977, 49:8|6-83।. 
56. Rabah FKJ, Dahab MF: Nitrate removal characteristics of high performance fluidized-bed biofilm reactors. Water Res 2004, 38:3719-3728.

57. Jesis JS, Owen RW: Biological fluid-bed treatment for BOD and nitrogen removal. J Water Pollut Control Fed 1977, 49:8I 6-82I.

58. Shieh WK, Keenan JD: Fluidized bed biofilm reactor for wastewater treatment. Adv Biochem Eng Biotechnol 1986, 33:|3|-|69.

59. Iza J: Fluidized bed reactors for anaerobic wastewater treatment. Water Sci Technol I99I, 24(8): I09-I32.

60. Ye FX, Shen DS, Feng XS: Anaerobic granule development for removal of pentachlorophenol in an upflow anaerobic sludge blanket (UASB) reactor. Process Biochem 2004, 39: I249- I 256.

61. Schmidt JE, Batstone DJ, Angelidaki I: Improved nitrogen removal in upflow anaerobic sludge blanket (UASB) reactors by incorporation of Annammox bacteria into the granular sludge. Water Sci Technol 2004, 49( I I-I 2):69-76.

62. Horber C, Christiansen N, Arvin E, Ahring BK: Improved dechlorinating performance of upflow anaerobic sludge blanket reactors by incorporation of Dehalospirillum multivorans into granular sludge. Appl Env Microbiol 1998, 64(5):|860-|863.

63. Iza J, Keenan PJ, Switzenbaum MS: Anaerobic treatment of municipal solid waste landfill leachate: Operation of a pilot scale hybrid UASB/AF reactor. Water Sci Technol 1992, 25(7):255-264.

64. Fang HHP, Hui HH: Effect of heavy metals on the methanogenic activity of starch-degrading granules. Biotechnol Lett 1994, I6(10): 1091-1096.

65. Satoh H, Nakamura Y, Ono H, Okabe S: Effect of oxygen concentration on nitrification and denitrification in single activated sludge flocs. Biotechnol Bioeng 2003, 83:604-607.

66. Pochana K, Keller J: Study of factors affecting simultaneous nitrification and denitrification (SND). Water Sci Technol 1999 39:61-68.

67. Robertson LA, van Niel EDJ, Torremans RAM, Kuenen JG: Simultaneous nitrification and denitrification in aerobic chemostat cultures of Thiosphaera pantotropha. Appl Environ Microbiol 1988, 54:2812-28|8.

68. Robertson LA, Cornelisse R, De Vos P, Hadioetomo R, Kuenen JG: Aerobic denitrification in various heterotrophic nitrifiers. Antonie van Leeuwenhoek (Historical Archive) 1989, 56:289-299.

69. Jensen K, Sloth NP, Risgaard-Petersen N, Rysgaard S, Revsbech NP: Estimation of nitrification and denitrification from microprofiles of oxygen and nitrate in model sediment systems. Appl Environ Microbiol 1994, 60:2094-2100.

70. van Niel EDJ, Braber KJ, Robertson LA, Kuenen JG: Heterotrophic nitrification and aerobic denitrification in Alcaligenes faecalis strain TUD. Antonie van Leeuwenhoek (Historical Archive) 1992, 62:231-237.

7I. Robertson LA, Kuenen JG: Thiosphaera pantotropha gen nov sp nov, a facultative anaerobic, facultative autotrophic sulphur bacterium. J Gen Microbiol 1983, I 29:2847-2855.

72. Robertson LA, Kuenen JG: Aerobic denitrification: a controversy revived. Archive Microbiol 1984, I39:35I-354.

73. Brindle K, Stephenson T: The application of membrane biological reactors for the treatment of wastewaters. Biotechno Bioeng 1996, 49:601-610.

74. Casey E, Glennon B, Hamer G: Oxygen mass transfer characteristics in a membrane-aerated biofilm reactor. Biotechnol Bioeng 1999, 62:183-192.

75. Debus O, Wanner O: Degradation of xylene by a biofilm growing on a gas permeable membrane. Water Sci Technol 1992, 26:607-616

76. Brindle K, Stephenson T: Nitrification in a bubbleless oxygen mass transfer membrane bioreactor. Water Sci Technol 1996, 34:26|-267.

77. Kennes C, Thalasso F: Waste Gas Biotreatment Technology. I Chem Technol Biotechnol 1998, 72:303-319.

78. Ottengraf SPP: Biological systems for waste gas elimination. Trends Biotechnol 1987, 5: 132-136.

79. Koe LCC, Yang F: A bioscrubber for hydrogen sulfide removal. Water Sci Technol 2000, 4 I: |4|-145.

80. Ottengraf S, Van Den Oever A: Kinetics of organic compound removal from waste gases with a biological filter. Biotechnol Bioeng 1983, 25:3089-3102.

8I. Shinabe K, Oketani S, Ochi T, Matsumura M: Characteristics of hydrogen sulfide removal by Thiobacillus thiooxidans KSI iso- lated from a carrier-packed biological deodorization system. J Ferment Bioeng 1995, 80:592-598.

82. De Beer D, Stoodley P, Roe F, Lewandowski Z: Effects of biofilm structures on oxygen distribution and mass transport. Biotechnol Bioeng 1994, 43: I I3I-II38.

83. Morgenroth E, Schroeder ED, Chang DPY, Scow KM: Nutrient limitation in a compost biofilter degrading hexane. J Air Waste Managem Assoc 1996, 46:300-308.

84. Bland RR, Chen HC, Jewell WJ, Bellamy WD, Zall RR: Continuous high rate production of ethanol by Zymomonas mobilis in an attached film expanded bed fermentor. Biotechnol Lett 1982 , 4:323-328.

85. Krug TA, Daugulis AJ: Ethanol production using Zymomonas mobilis immobilized on an ion exchange resin. Biotechnol Lett 1983, 5:159-164.

86. Kunduru MR, Pometto AL III: Continuous ethanol production by Zymomonas mobilis and Saccharomyces cerevisiae in biofilm reactors. J Ind Microbiol Biotechnol 1996, 16:249-256.

87. Qureshi N, Brining H, Iten L, Dien B, Nichols N, Saha B, Cotta MA: Adsorbed cell dynamic biofilm reactor for ethanol production from xylose and corn fiber hydrolysate. The 36th Great Lakes Regional Meeting of the American Chemical Society, Peoria, IL, October 17-20, 2004

88. Rogers PL, Lee KJ, Skotnicki ML, Tribe DE: Ethanol production by Zymomonas mobilis. Adv Biochemical Eng 1982, 23:37-84.

89. Welsh FW, Williams RE, Veliky IA: Solid carriers for a Clostridium acetobutylicum that produced acetone and butanol. Enz Microbial Technol 1987, 9:500-502.

90. Qureshi N, Lai LL, Blaschek HP: Scale-up of a high productivity continuous biofilm reactor to produce butanol by adsorbed cells of Clostridium beijerinckii BAIOI. Transactions Institution Chemical Engineers (Trans IChemE) (Chemical Engineering Research and Design) 2004, 82(C2): I64-I73.

91. Qureshi N, Blaschek HP: Butanol production from agricultural biomass. In Advances in Food Biotechnology Edited by: Shetty K, Pometto A, Paliyath G. New York, NY: CRC Press; 2005 in press.

92. Ezeji TC, Qureshi N, Blaschek HP: Industrially relevant fermentations. In Handbook on Clostridia Edited by: Durrie P. New York, NY: CRC Press; 2005.

93. Pierrot $P$, Fick $M$, Engasser JM: Continuous acetone butanol fermentation with high productivity by cell ultrafiltration and recycling. Biotechnol Lett 1986, 8:253-256.

94. Afschar AS, Biebl H, Schaller K, Schugerl K: Production of acetone and butanol by Clostridium acetobutylicum in continuous culture with cell recycle. Appl Microbiol Biotechnol 1985, 22:394-398.

95. Shazer WH, Speckman RA: Continuous fermentation of whey permeate by Bacillus polymyxa. J Dairy Sci 1984, 67(Suppl I, D5G): $1216-1218$.

96. Syblayrolles JM, Goma G: Butanediol production by Aerobactor aerogenes NRRL B 199: effect of initial substrate concentration and aeration agitation. Biotechnol Bioeng 1984, 26: |48-I 55.

97. Ramachandran KB, Goma G: Effect of oxygen supply and dilution rate on the production of 2,3-butanediol in continuous bioreactor by Klebsiella pneumoniae. Enz Microbial Technol 1987, 9:|07-III.

98. Lee HK, Maddox IS: Continuous production of 2,3-butanediol from whey permeate using Klebsiella pneumoniae immobilized in calcium alginate. Enz Microbial Technol 1986, 8:409-4I I.

99. Ramachandran KB, Goma G: 2,3-butanediol production from glucose by Klebsiella pneumoniae in a cell recycle system. J Biotechnol 1988, 9:39-46.

100. Zeng AP, Biebl H, Deckwer WD: Production of 2,3-butanediol in a membrane bioreactor with cell recycle. Appl Microbiol Biotechnol I991, 34:463-468.

10I. Demirci A, Pometto AL III, Johnson KE: Evaluation of biofilm reactor solid support for mixed-culture lactic acid production. Appl Microbiol Biotechnol 1993, 38:728-733.

102. Demirci A, Pometto AL III, Johnson KE: Lactic acid production in a mixed-culture biofilm reactor. Appl Environ Microbiol 1993 , 59:203-207.

103. Ho KLG, Pometto AL III, Hinz PN, Demirci A: Nutrient leaching and end product accumulation in plastic composite supports for L-(+)-lactic acid biofilm fermentation. Appl Environ Microbiol 1997, 63:2524-2532.

104. Ho KLG, Pometto AL III, Hinz PN: Optimization of L-(+)-lactic acid production by ring and disc plastic composite supports 
through repeated-batch biofilm fermentation. Appl Environ Microbiol 1997, 63:2533-2542.

105. Ho KLG, Pometto AL III, Hinz PN, Dickson JS, Demirci A: Ingredient selection for plastic composite supports for L-(+)-lactic acid biofilm fermentation by Lactobacillus casei subsp. rhmnosus. Appl Environ Microbiol 1997, 63:2516-25।3.

106. Park EY, Kosakai Y, Okabe M: Efficient production of L-(+)-lactic acid using mycelial cotton-like flocs of Rhizopus oryzae in an air-lift bioreactor. Biotechnol Prog 1998, 14:699-704.

107. Sun Y, Li YL, Bai S: Modeling of continuous L(+)-lactic acid production with immobilized $R$. oryzae in an airlift bioreactor. Biochem Eng J 1999, 3:87-90.

108. Cao N, Du J, Gong CS, Tsao GT: Simultaneous production and recovery of fumaric acid from immobilized Rhizopus oryzae with a rotary biofilm contactor and an adsorption column. Appl Env Microbiol 1996, 62:2926-2931.

109. Zeikus JG, Jain MK, Elankovan P: Biotechnology of succinic acid production and markets for industrial products. Appl Microbio Biotechnol 1999, 5 I:545-552.

1 10. Urbance SE, Pometto AL III, DiSpirito AA, Demirci A: Medium evaluation and plastic composite support ingredient selection for biofilm formation and succinic acid production by Actinobacillus succinogenes. Food Biotechnol 2003, 17:53-65.

1II. Cotton JC, Pometto AL III, Gvozdenovic-Jeremic J: Continuous lactic acid fermentation using a plastic composite support biofilm reactor. Appl Microbiol Biotechnol 200I, 57:626-630.

1 12. Costerton JW, Cheng KJ, Geesey GG, Ladd TI, Nickel JC, Dasgupta M, Marrie TJ: Bacterial biofilms in nature and disease. Annu Rev Microbiol 1987, 41:435-464.

1 13. O'Toole G, Kaplan HB, Kolter R: Biofilm formation as microbial development. Annu Rev Microbiol 2000, 54:49-79.

Publish with Bio Med Central and every scientist can read your work free of charge

"BioMed Central will be the most significant development for disseminating the results of biomedical research in our lifetime. "

Sir Paul Nurse, Cancer Research UK

Your research papers will be:

- available free of charge to the entire biomedical community

- peer reviewed and published immediately upon acceptance

- cited in PubMed and archived on PubMed Central

- yours - you keep the copyright

Submit your manuscript here:

http://www.biomedcentral.com/info/publishing_adv.asp
BiolMedcentral 